STEPHANE TEREZA QUEIROZ DE ANDRADE

INFLUÊNCIA DO GENE SCL11A1 NO DESENVOLVIMENTO DA Colite Por Sulfato Sódico de Dextrana EM MOdelo MURINO DE INFLAMAÇÃO AGUDA

Dissertação apresentada ao Programa de Pós Graduação de Imunologia do Instituto de Ciências Biomédicas da Universidade de São Paulo, para obtenção do Título de Mestre em Ciências. 


\section{INFLUÊNCIA DO GENE SCL11A1 NO DESENVOLVIMENTO DA Colite por Sulfato Sódico de Dextrana em Modelo MURINO DE INFLAMAÇÃO AGUDA}

Dissertação apresentada ao Programa de Imunologia do Instituto de Ciências Biomédicas da Universidade de São Paulo, para obtenção do Título de Mestre em Ciências.

Área de concentração: Instituto de Ciências Biomédicas

Orientador: Prof. Dr. Orlando Garcia Ribeiro Filho

Coorientador: Dra. Solange Massa

Versão original.

\section{São Paulo}

2019 


\section{Dedicatória}

Dedico esse trabalho á minha mãe biológica Ornelina Andrade e Silva (in memoriam), que infelizmente não pode acompanhar de perto o meu crescimento, mas me deixou aos cuidados da melhor pessoa do mundo, minha mãe Josefina Varga Andrade Silva. 


\section{Agradecimentos}

\section{A Deus}

\section{A minha família}

Por sempre terem sempre me apoiado, respeitado minhas escolhas e permanecido ao meu lado quando eu mais precisei nunca desistindo de mim.

\section{Aos meus amigos e colegas de laboratório}

Aline Vasconcelos, Bridilla Luiza, Bruna Favoretto, Eronita Garcia, Letícia Monteleone, Mara Irineu, Paula Diana, Rebecca Rodrigues, Ronaldo Mateus, Tamíris Guidugli, Thamara Gonçalves, por todas as risadas, desabafos, conselhos e doces.

\section{Aos meus amigos e colegas do Biotério}

Aline Dias, Antônio Luiz, Breno Almeida, Cristiane Garramoni, Gustavo Gonçalves por toda ajuda e companhia.

\section{Aos pesquisadores do Laboratório}

Andrea Borrego, Aryene Goes, José Ricardo, Milene Silva, Mônica Spadafora, Nancy Starobinas, Olga Ibañez, Solange Massa, Wafa Cabrera por toda ajuda, conselhos e ensinamentos durante esse período.

\section{Ao meu Orientador}

Orlando Garcia Ribeiro Filho, pela paciência, dedicação e ensinamentos.

\section{A CAPES}

Por ter me financiado durante o meu trabalho 


\section{Epígrafe}

"O cientista não é o homem que fornece as verdadeiras respostas; é quem faz as verdadeiras perguntas". (Claude Lévi-Strauss) 


\section{Resumo}

Andrade, S T Q. Influência do gene Scl11a1 no desenvolvimento da colite induzida por sulfato sódico de Dextrana em modelo murino de inflamação aguda. 2019. 75 f. Dissertação (Mestrado em Imunologia) - Instituto de Ciências Biomédicas, Universidade de São Paulo, São Paulo, 2019.

A colite ulcerativa é considerada uma doença inflamatória caracterizada por processo crônico de lesão da mucosa do cólon e associada a um risco aumentado para carcinogênese. A patogênese da doença envolve fatores ambientais e genéticos com participação ativa de células inflamatórias fagocíticas, particularmente macrófagos ativados. Estudos genéticos em humanos indicam a associação de variantes do gene, que codifica a proteína transportadora de íons Slc11a1 (ou Nramp1), com a suscetibilidade a esta doença, assim como resistência ou suscetibilidade à infecção por parasitas intracelulares em várias espécies animais. Essa proteína tem efeitos pleiotrópicos sobre macrófagos, influenciando suas atividades inflamatórias, tumoricida e antimicrobiana. $\mathrm{O}$ modelo de estudo experimental mais adequado para o desenvolvimento da colite ulcerativa tem sido realizado por meio da ingestão de Sulfato Sódico de Dextrana em animais suscetíveis. Os camundongos selecionados geneticamente para alta (AIRmax) ou baixa resposta (AIRmin) inflamatória aguda ao Biogel representam um modelo alternativo àqueles que utilizam linhagens isogênicas mutantes para os alelos do gene Slc11a1. Os camundongos AIRmax e AIRmin apresentaram um desequilíbrio de frequência do alelo $\mathrm{S}$ do gene Slc1lal ao longo do processo seletivo, $9 \%$ e 60\%, respectivamente. Para estudar os efeitos desses alelos na modulação dos fenótipos de resistência ou suscetibilidade à infecção e resposta inflamatória aguda, foram obtidas, por cruzamentos assistidos pelo genótipo, quatro linhagens homozigotas para os alelos $\mathrm{R}$ e $\mathrm{S}$ do referido gene com fundo genético de AIRmax e AIRmin. Com este modelo, nos propomos estudar a relação entre o desenvolvimento de colite ulcerativa em resposta ao DSS e a presença dos alelos R ou S do gene Slc1lal em animais selecionados para AIR com estes alelos fixados, $\operatorname{AIRmax}^{R R}, \operatorname{AIRmax}^{S S}, \operatorname{AIRmin}^{R R} e$ AIRmin $^{S S}$. Para isso avaliamos o IAD (Índice de Atividades de Doença), considerando a perda de peso, a presença de diarreia e de sangue no ânus e/ou nas fezes como parâmetros. Também consideramos a análise histológica do cólon por meio da determinação de escores para algumas categorias tais como, infiltrado inflamatório, modificações epiteliais e destruição da sua arquitetura; atividade da mieloperoxidase, como medida indireta de inflamação, produção de citocinas pró- e anti-inflamatórias no tecido e populações celulares presente no epitélio do órgão. Nossos resultados apontam para uma maior sensibilidade dos animais AIRmin $^{S S}$ aos efeitos do DSS, apresentando um IAD significativamente maior do que as demais linhagens. Além disso, parâmetros inflamatórios como MPO, IL6, G-CSF e MCP-1 e estruturais como redução do comprimento do cólon e caracterização histopatológica do tecido mostraram alterações importantes, destacando os camundongos $\operatorname{AIRmin}^{S S}$ como um modelo de sensibilidade. Concluindo, o presente estudo sugere a influência do gene Slcllal no fenótipo de resistência à UC, independente da constituição genética do indivíduo. Por outro lado, quando ocorre a fixação do alelo $\mathrm{S}$, no caso representativo dos animais $A$ IRmin $^{S S}$, uma interação com o background genético de baixa resposta inflamatória é importante na determinação da sensibilidade à doença.

Palavras Chave: Inflamação, Colite Ulcerativa, Seleção Genética, Sulfato Sódico de Dextrana (DSS) 


\begin{abstract}
Andrade, S T Q Influence of the Scl11a1 gene on the development of dextran sodium sulfate (DSS)induced-colitis in murine model of acute inflammation. 2019. 75 f. Dissertação (Mestrado em Imunologia) - Instituto de Ciências Biomédicas, Universidade de São Paulo, São Paulo, 2019.

Ulcerative colitis (UC) is considered an inflammatory disease characterized by a chronic process of colon mucosa lesion and associated with an increased risk for carcinogenesis. The pathogenesis of the disease involves environmental and genetic factors with active participation of inflammatory phagocytic cells, particularly activated macrophages. Genetic studies in humans indicate the association of variants of the gene encoding the ions carrier protein SLC11A1 (or Nramp1) with susceptibility to UC, as well as resistance or susceptibility to infection by intracellular parasites in several animal species. This protein has pleiotropic effects on macrophages, influencing its inflammatory, tumoricidal and antimicrobial activities. The most suitable experimental study model for the development of UC has been the use of Sodium Sulfate Dextran in susceptible animals. Genetically selected mice for high (AIRmax) or low (AIRmin) inflammatory response to Biogel represent an alternative model to those that use isogenic mutant strains for the Slc1lal alleles. The AIRmax and AIRmin mice showed an allelic imbalance of the Slc11a1 gene of $9 \%$ and $60 \%$, respectively. In order to study the effects of these alleles on the modulation of resistance or susceptibility phenotypes to infection and acute inflammatory response, four lines of mice homozygous for the R and S alleles of said AIRmax and AIRmin gene gene were obtained by crosses assisted by the genotype. Therefore, we propose to study the relationship between the development of UC induced by DSS and the presence of the R or S alleles of the Slc11a1 gene in selected mice for AIR with the fixed alleles, $\operatorname{AIRmax}^{R R}, \operatorname{AIRmax}^{S S}, \operatorname{AIRmin}^{R R}$ and $\operatorname{AIRmin}^{S S}$. For that, we evaluated as UC parameters, DAI (Disease Activity Index), considering weight loss, diarrhea and presence of blood in anus or feces. We also considered the histopatological analysis of the colon by scores for some categories such as, inflammatory infiltrate, epithelial modifications and destruction of its architecture, myeloperoxidase activity as an indirect measure of inflammation, production of pro- and antiinflammatory cytokines in tissue and cell populations in the distal colon epithelium. Our results point to a greater sensitivity of the AIRmin ${ }^{S S}$ mice to the effects of the DSS, presenting DAI significantly higher than in the others mice. In addition, inflammatory parameters such as MPO, IL6, G-CSF and MCP-1 and structural factors such as reduction of colon length and histopathological alterations, highlighting the AIRmin $^{S S}$ mice as the most sensible. In conclusion, the present study suggests the influence of the Slc1lal ${ }^{R R}$ allele on resistance to UC, independently of the individual genetic constitution. On the other hand, when the $S$ allele fixation occurs, in the case of $\operatorname{AIRmin}^{S S}$, an interaction with genetic background of low inflammatory response is important in determining the UC.
\end{abstract}

Keywords: Inflammation, Ulcerative Colitis (UC), Genetic Selection, Dextran Sodium Sulfate (DSS) 


\section{Lista de Ilustrações}

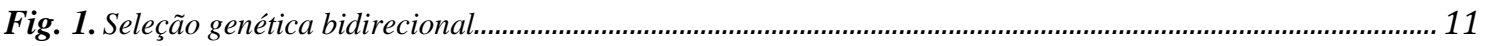

Fig.2. Protocolo de indução da colite utilizando DSS-MP 2,5\%.......................................................................... 15

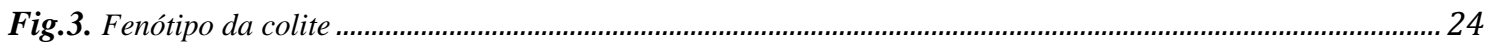

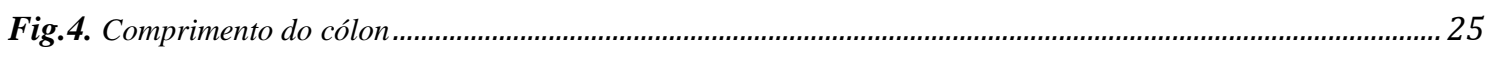

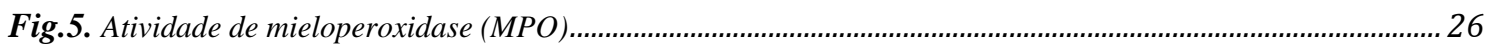

Fig.6. Fotomicrografias das porções distais do Cólon obtidas dos animais AIRmaxRR, AIRmaxSS, AIRminRR e

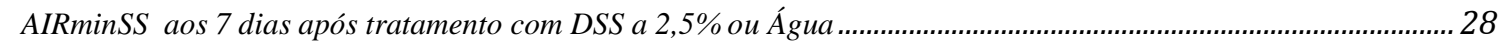

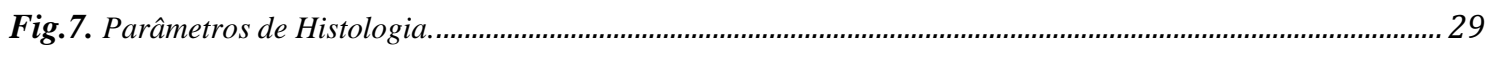

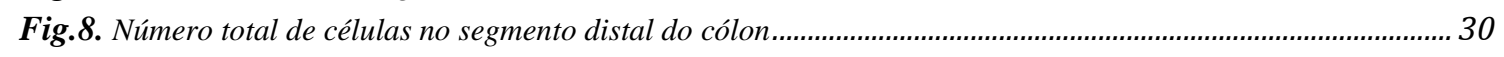

Fig.9. Análise por citometria do infiltrado inflamatório no segmento distal .............................................................32

Fig.10. Análise por citometria das populações celulares presentes na mucosa do cólon no segmento distal ............ 33

Fig.11. Análise por citometria das populações de macrófagos no segmento distal................................................ 35

Fig.12. Análise por citometria das populações de macrófagos com função reguladora no segmento distal ..............36

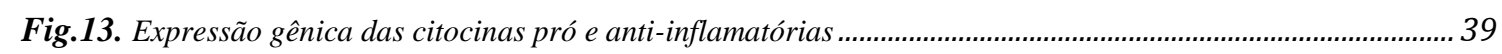

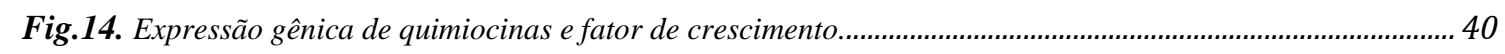

Fig.15. Concentração de citocinas pró e anti-inflamatórias no cólon ...................................................................... 42

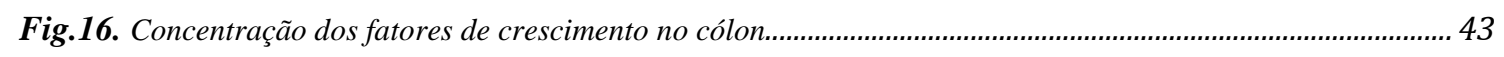

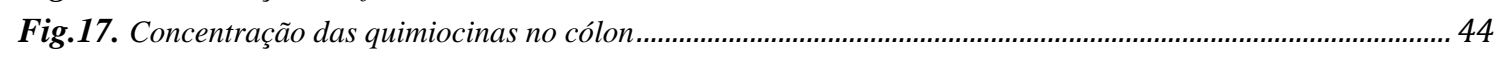




\section{Lista de Tabelas}

Tabela 1. Escores utilizados no cálculo do IAD baseado no trabalho de WIRTZ, S. et al, 2007

Tabela 2. Escores utilizados na classificação dos parâmetros Histológicos por Erben et al, 2014 18

Tabela 3. Mediana dos escores dos animais dos grupos AIRmaxRR, AIRmax SS AIRmin RR AIRmin SS segundo os parâmetros da Tabela 1

Tabela 4. Resumo dos resultados com destaque (*) para os parâmetros mais diferenciados a favor dos animais AIRminsS. ... 45 


\section{Lista de Abreviações}

AJ- Junções de Adesão

AIR -Resposta Inflamatória Aguda

DNBS - Ácido Dinitrobenzenesulfônico

DSS- Dextran Sulfato de Sódio

ER- Reticulo Endoplasmático

G-CSF- Fator Estimulador de Colônias de Granulócitos

GM-CSF- Fator Estimulador de Colônias de Granulócitos e Macrófagos

GWAS - Genome Wide Association Studies

HE-Hematoxilina \& Eosina

IAD- Índice de Atividade da Doença

IBD- Doeças Inflamatórias Gastrointestinais- do inglês Inflammatory Bowel Disease

IECs- Células Epiteliais Intestinais

IL-1及- Interleucina $1 \beta$

IL-4- Interleucina 4

IL-6- Interleucina 6

IL-10- Interleucina 10

IL-17- Interleucina 17

ILCs -Células Linfóides Inatas- do inglês Innate Lymphoid Cells

INF- $\boldsymbol{\gamma}$-Interferon $\boldsymbol{\gamma}$

iNOS- enzima óxido nítrico sintetase

LPS-Lipopolissacarídeo

MCP-1-Proteíma de quimioatração de monócitos- do inglês Monocyte Chemoattractant Protein-1

M-CSF- Fator Estimulador de Colônias de Macrófagos 
MHC- complexo de histocompatibilidade principal

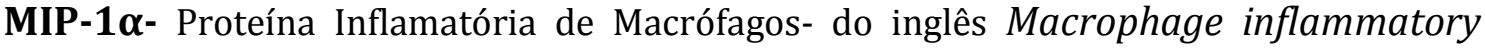
protein

MPO- Mieloperoxidase

MUC2-Mucina Tipo 2

NLR- Receptores do tipo Nod- do inglês Nod Like Receptor

NO- óxido nítrico

Nramp1- Proteína de Resistência Natural Associada a Macrófagos-do inglês Natural Resistance Associated Macrophage Protein

PRRs- Receptores de Reconhecimento de Padrões do Inglês Pattern Recognition Receptors

ROS- radicais de oxigênio

Scl11a1- Solute Carrier Family 11 Member

SNPs -Polimorfismo de nucleotídeo único - do inglês Single Nucleotide Polymorphism

STAT3-Signal Transducer and Activator of Transcription-3

TA-Temperatura ambiente

TJ-Tight Juctions

TLR- Receptores do tipo Nod- do inglês Toll Like Receptor

TM- Dominínios de Membrana

TNF $\boldsymbol{\alpha}$ - fator de necrose tumoral alfa

UC- Colite Ulcerativa- do inglês Ulcerative Colitis 


\section{Sumário}

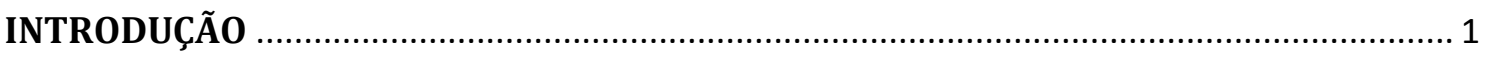

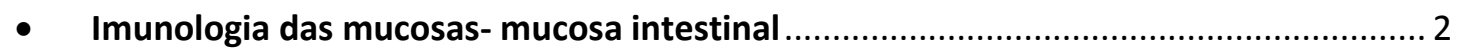

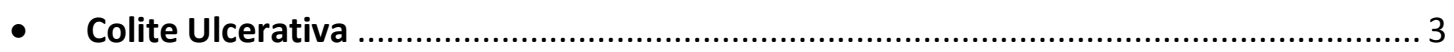

Indução de colite por Sulfato Sódico de Dextrana - DSS ……................................................ 6

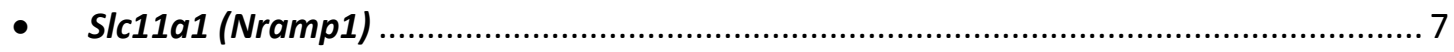

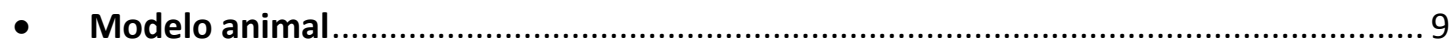

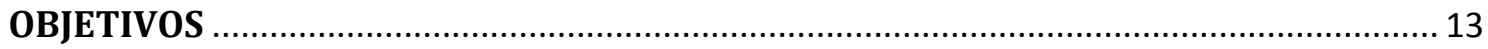

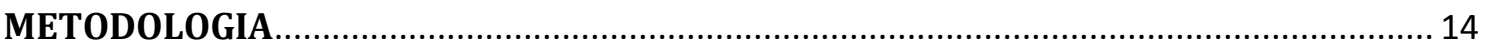

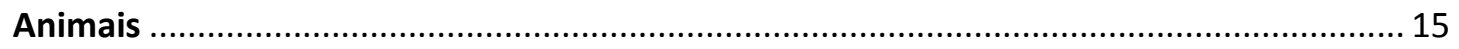

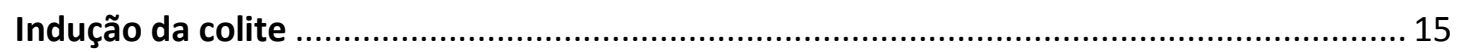

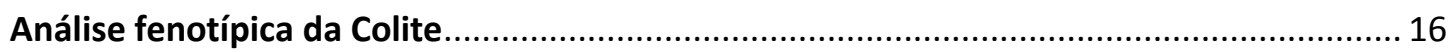

Determinação da atividade da mieloperoxidase (MPO) …............................................... 17

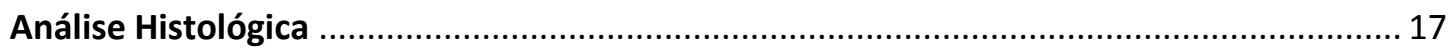

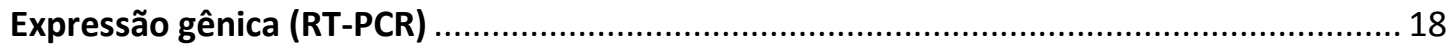

Extração e purificação de RNA (RNAspin Mini Kit Healthcare).............................................18

Real Time PCR (RT-PCR).........................................................................................................18

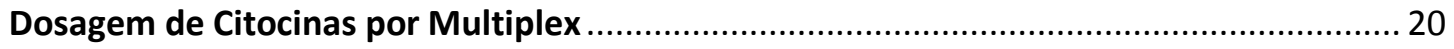

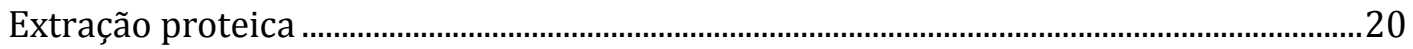

Determinação do nível de citocinas por Multiplex....................................................................20

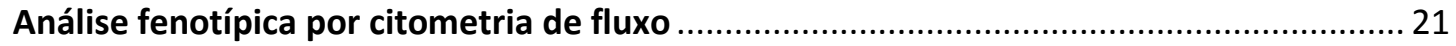

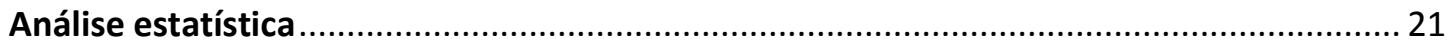

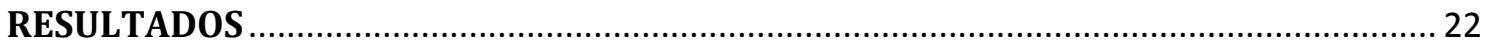

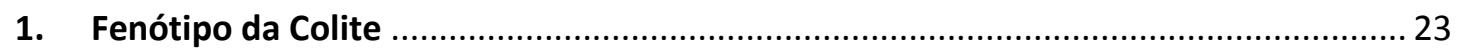

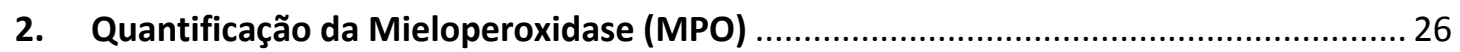

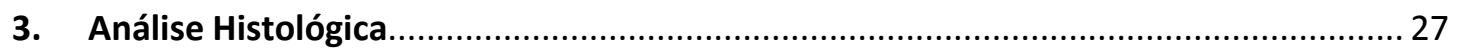

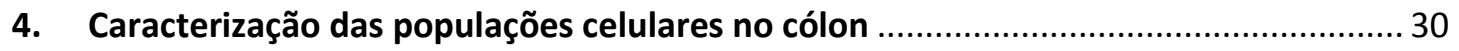

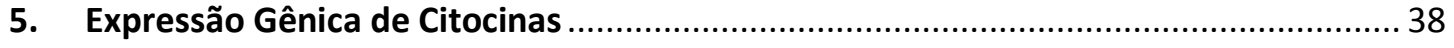

6. Diferença na Produção de Citocinas ............................................................................. 41

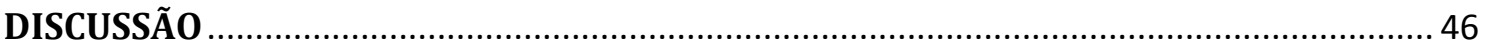

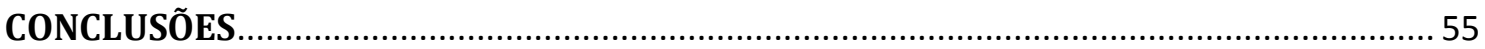

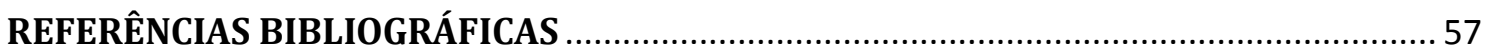


INTRODUÇÃO 


\section{- Imunologia das mucosas- mucosa intestinal}

O intestino é um ambiente propício para albergar diversos microrganismos devido à grande quantidade de nutrientes oriundos dos alimentos presentes na forma aeróbica no lúmen intestinal. Esses microrganismos compõem a microbiota e são separados do sistema imunológico do hospedeiro por um sistema de barreiras que bloqueiam, quando íntegras, as reações imunológicas do hospedeiro e as eventuais interações com patógenos.

As mucosas constituem essas barreiras, que além de proteção, desempenham as funções de absorção, secreção, transporte de macromoléculas entre outros. Em condições infecciosas é necessário que exista um balanço entre a resposta inflamatória gerada contra agentes infecciosos e a tolerância à microbiota residente (Odenwald; Turner, 2017; Wells et al, 2016).

O trato gastrointestinal é o que apresenta a maior superfície de mucosas (cerca de $400 \mathrm{~m}^{2}$ ) e tem a função de absorver nutrientes necessários ao organismo ao mesmo tempo em que impede a entrada de patógenos. Para essa finalidade existem barreiras físicas e químicas (Bischoff et al, 2014). A primeira delas é uma camada de muco que recobre toda a mucosa formada pela mucina tipo 2 (MUC2) secretada pelas globet cells. Essa camada é subdividida em duas partes: uma mais interna, que tem a função de impedir o contato da microbiota com as células epiteliais intestinais, e uma mais externa que se forma devido à atividade proteolítica da MUC2 pelas bactérias que compõem a microbiota (Geremia et al, 2014; Vancamelbeke; Vermeire, 2017; Okumura ; Takeda, 2018).

A segunda seria formada pelas células epiteliais intestinais (IECs) que formam tanto uma barreira física quanto química através da secreção de peptídeos antimicrobianos como as Defensinas. Na monocamada de células epiteliais estão presentes os complexos juncionais (TJ do inglês, Tight Junctions) que controlam o fluxo paracelular de grandes moléculas, formadas por proteínas transmembrânicas como Claudinas e Ocludinas e complexos juncionais; e abaixo estão presentes as Junções de 
Adesão (AJ) e desmossomos, que mantêm a integridade do epitélio por meio da adesão célula-célula e também participam da sinalização celular sendo formadas principalmente por Caderinas (Bischoff et al, 2014; Odenwald; Turner, 2017; Vancamelbeke ; Vermeire, 2017; Wells et al, 2016).

Essas barreiras não apenas impedem a infecção por agentes patogênicos como também regulam a permeabilidade intestinal. Quando ocorre uma inflamação, como em casos de Doenças Inflamatórias Gastrointestinais (IBD -Inflammatory Bowel Disease), doenças celíacas, alergias a determinados alimentos e estágio iniciais de câncer de cólon, onde há a produção de citocinas inflamatórias, pode haver um aumento de permeabilidade, o que por sua vez pode contribuir para a severidade da doença (Bischoff et al, 2014; Wells et al, 2016).

Outra característica da mucosa intestinal é ser considerado um ambiente de tolerância, de modo a montar uma resposta contra patógenos e ao mesmo tempo se manter tolerante com relação à microbiota comensal e antígenos considerados inofensivos (Neurath ; Finotto; Glimcher, 2002). O reconhecimento da microbiota e de bactérias e outros organismos patogênicos dá-se através dos PRRs (Pattern Recognition Receptors) como TLRs (Toll Like Receptor) e NLRs (Nod Like Receptors). No entanto, no caso das espécies comensais que estão presentes na microbiota, esse reconhecimento leva a respostas imunorreguladoras (Littman; Pamer, 2011; Palm ; De Zoete; Flavell, 2015). Isto ocorre pela produção de citocinas anti-inflamatórias como IL-10 e TGF- $\beta$, indução de hiporresponsividade de células T pelas células dendríticas, diferenciação de células $\mathrm{T}_{\text {reg }}$ e produção de IgA pelos Linfócitos B (Coombes; Maloy, 2007; Mann; Li, 2014; Neurath; Finotto; Glimcher, 2002).

\section{- Colite Ulcerativa}

Quando a homeostasia intestinal é quebrada, isso pode levar a um quadro de inflamação como é o caso das IBDs (do inglês: Inflammatory Bowel Disease). A colite ulcerativa (UC - do inglês: Ulcerative Colitis), juntamente com a Doença de Crohn, é classificada como uma doença inflamatória gastrointestinal caracterizada por uma inflamação crônica da mucosa intestinal, seguido por períodos de remissão (Hisamatsu et al, 2013; Molodecky et al, 2012; Shouval; Rufo, 2017). Nos últimos 50 anos, houve um aumento na incidência de IBD, onde $60 \%$ correspondem à UC, sendo que as maiores incidências de colite ulcerativa foram relatadas no norte da Europa (24,3 por 
100.000), no Canadá (19,2 por 100.000) e na Austrália (17,4 por 100.000). As taxas de prevalência são mais elevadas na Europa (505 por 100.000), no Canadá (248 por 100.000) e nos EUA (214 por 100.000) (Molodecky et al, 2012; Ungaro; Mehandru; Allen et al, 2017).

Embora sua etiologia ainda permaneça desconhecida, mas considerada como uma interação entre suscetibilidade genética, fatores ambientais, microbiota intestinal e disfunção imunológica, acredita-se que ela esteja associada ao estilo de vida ocidentalizado, devido ao alto índice de incidência progressiva nos países desenvolvidos nas últimas décadas (Tatiya-Aphiradee; Chatuphonprasert; Jarukamjorn, 2018). Fatores como industrialização e urbanização das sociedades modernas acompanhadas de mudanças nas exposições a microrganismos patogênicos, a poluentes ambientais e a medicamentos, falta de saneamento básico de países pobres e mudanças nos comportamentos de estilo de vida, propiciaram o desenvolvimento potencial de fatores de risco para IBD. Um fato curioso é que imigrantes de países subdesenvolvidos são mais sensíveis a fatores ambientais de risco de IBD, como por exemplo, uso de antibióticos, que leva a mudanças bruscas da microbiota, bem como o estilo de vida ocidentalizado. (Ko et al, 2015; Molodecky et al, 2012; Shouval; Rufo, 2017).

Dentre os fatores que podem acarretar em inflamação intestinal e no desenvolvimento da UC, podemos citar as predisposições genéticas e hereditariedade (cerca de $23 \%$ ) e os fatores ambientais.

Com relação aos fatores de risco genéticos, os estudos de associação do genoma (GWAS - Genome Wide Association Studies) identificaram 200 loci gênicos não sobrepostos, incluindo 28 que são compartilhados entre a doença de Crohn e a colite ulcerativa. Os genes localizados nesses loci foram identificados como relacionados à homeostase intestinal incluindo função de barreira, restituição epitelial, defesa microbiana, regulação imune inata, geração de espécies reativas de oxigênio (ROS), autofagia, regulação da imunidade adaptativa e estresse do retículo endoplasmático (ER). Recentemente, a presença de SNPs (Single Nucleotide Polymorphism) no fator de transcrição $H N F 4 A$, que regula a montagem do complexo de junção apical, também foi relacionada à UC (Geremia et al, 2014; Hisamatsu et al, 2013; Kohr; Gardet; Xavier, 2011; Ungaro; Mehandru; Allen et al, 2017). 
Como fatores ambientais, destacamos: (i) o tipo de parto, se normal ou cesariana, que influencia na formação e composição da flora intestinal e também no desenvolvimento e função das células imunes intestinais; (ii) amamentação, cujos estudos descrevem um papel protetor contra IBD; (iii) dieta, pois o alto consumo de carnes e produtos processados com baixo conteúdo de fibras foram relacionados com um aumento do risco para IBD; (iv) infecções por parasitas, que também aumentam o risco de IBD; e $(v)$ situações prolongadas ou recorrentes de estresse que podem levar à inflamação intestinal por meio de mecanismos entéricos, neuronais ou hormonais e com produção de citocinas pró-inflamatórias e alteração da permeabilidade intestinal. Curiosamente o tabagismo parece ter um efeito protetor da colite (Hisamatsu et al, 2013; Legaki, 2016; Shouval; Rufo, 2017; Tatiya-Aphiradee; Chatuphonprasert; Jarukamjorn, 2018).

A UC é caracterizada por inflamação que é limitada ao cólon, iniciando no reto, podendo abranger apenas uma porção ou todo o cólon (pancolite) e se espalha de forma contínua com alterações inflamatórias superficiais limitadas à mucosa e submucosa, levando a perda de células caliciais (globet cells), hiperplasia, abscessos de cripta e, mais gravemente, ulceração (Erben et al, 2016; Ungaro; Mehandru; Allen et al, 2017; Tatiya-aphiradee; Chatuphonprasert; Jarukamjorn, 2018). A inflamação na colite é bastante associada a uma resposta Th2 não convencional com produção aumentada de citocinas IL-5 e IL-13. No entanto, a presença de Th17 e ILCs (Innate Lymphoid Cells) também se mostrou importante para a patogênese dessa doença, através da secreção de IL-17 e IL-23 que ajudam a criar um ambiente inflamatório e também a infiltração de plasmócitos produtores de IgG (Geremia et al, 2014; Hisamatsu et al, 2013; Jiang et al, 2009; Kohr; Gardet; Xavier, 2011).

Os macrófagos (MФs) são células fagocíticas que compõem uma importante população residente nos tecidos e desempenham um papel fundamental no reconhecimento e na eliminação de bactérias assim como também na homeostase. (Hisamatsu et al, 2013). Os MФs residentes do intestino apresentam diferenças em relação aos esplênicos, pois apesar de apresentarem atividade bactericida e capacidade fagocítica, não apresentam produção de mediadores inflamatórios em resposta aos receptores TLR e sua atividade está voltada para regulação da resposta inflamatória e manutenção do epitélio através da produção de citocinas anti-inflamatórias (IL-10 e 
TGF- $\beta$ ), ajudando a manter a população de células $\mathrm{T}$ reguladoras juntamente com as células dendríticas (Bain; Mowat, 2014; Mann ; Li, 2014; Qualls et al, 2006)

No entanto, foi documentado que os MФs desempenham um papel importante nas IBDs, por meio da produção de mediadores como TNF- $\alpha$, IL-1, IL-6, radicais de oxigênio e ativação de linfócitos, podendo levar à cronificação da doença (Kojima et al, 2001; Lissner et al, 2015; Okayasu, 1990). Além disso, foi reportado por Grimm e colaboradores que macrófagos CD14 positivos são uma das maiores populações celulares presentes na mucosa em casos de inflamação (Grimm et al, 1995).

Portanto já que estas células desempenham um papel significativo na patogênese da doença e o gene Slcllal apresenta vários efeitos pleiotrópicos em suas funções, o estudo da expressão fenotípica de seus alelos na modulação da UC é de grande interesse.

\section{Indução de colite por Sulfato Sódico de Dextrana - DSS}

Existem muitos modelos de inflamação da mucosa para simular a patologia da UC, um deles é por meio da administração do agente químico Dextran Sulfato de Sódio (DSS). O DSS é um derivado polianiônico de dextran, um polímero de glicose sintetizado naturalmente por bactérias como Leuconostoc e Streptococcus, produzido por esterificação com ácido clorossulfúrico (Jurjus; Khoury; Reimund, 2004; Solomon et al, 2010).

A introdução de DSS como modelo experimental em camundongo para a indução do fenótipo de colite foi feita por Okayasu proposta pela primeira vez em 1990. A partir deste trabalho, diversos estudos demonstraram que o DSS em concentrações que variaram de 1 a $6 \%$ oferecido na água aos animais resultou em inflamação aguda ou crônica no cólon, dependendo do protocolo de administração (Okayasu, 1990; Perse \& Cerar, 2012; Solomon et al, 2010). A colite induzida por DSS se inicia no reto e depois se expande para a região distal do cólon, e a inflamação geralmente se limita à mucosa, podendo se expandir para a submucosa com a formação de edemas e ulcerações. Os sintomas clínicos incluem diarreia, sangue oculto e sangramento retal grave, de modo que é possível avaliar os diferentes aspectos da colite produzida por DSS no que concerne à avaliação clínica, fatores patológicos e genéticos, conforme revisado por 
Martina Perse e Anton Cerar ( Okayasu, 1990; Perse \& Cerar, 2012; Solomon et al, 2010)

O exato mecanismo que permite o DSS induzir a colite não é totalmente esclarecido. Sabe-se que o DSS provoca mudanças na barreira epitelial e alterações da permeabilidade intestinal antes do início da reação inflamatória, levando à ruptura das criptas intestinais e agressão às células epiteliais (Chassaing et al, 2013; Eichele; Kharbanda, 2017; Solomon et al, 2010; Strober; Fuss; Blumberg, 2002). Esse processo pode estar relacionado ao aumento de apoptose nas células epiteliais devido a uma paralisação do ciclo celular pelo DSS (Araki, et al, 2012), o que pode explicar o aumento de toxicidade dependente do tempo, concentração e também do peso molecular do DSS (Ni; Chen; Hollander, 1996; Perse, , \& Cerar, 2012). Além disso, foi mostrado que o DSS pode se ligar a várias moléculas da matriz extracelular como fibronectina e colágeno através de interação iônica, afetar a expressão de moléculas de adesão e modificar a composição da microbiota (Ni; Chen; Hollander, 1996; Nell; Suerbaum; Josenhans, 2010). Devido a essas alterações e ao aumento na permeabilidade intestinal há um encontro da microbiota intestinal com a população celular presente na mucosa subjacente causando inflamação, ulceração, alta infiltração de neutrófilos, macrófagos e células NK e uma resposta do tipo Th1 com altos níveis de produção de INF- $\gamma$, TNF- $\alpha$ IL-1 $\beta$, e posteriormente, cicatrização e reparo tecidual (Eichele ; Kharbanda, 2017; Jurjus; Khoury; Reimund, 2004; Kitajima; Takuma; Morimoto, 1999; Strober; Fuss; Blumberg, 2002; Takeda; Kiyoshi, et al, 1999).

Para uma melhor compreensão da Colite Ulcerativa, modelos animais têm sido utilizados e, apesar de não representarem a complexidade total da doença, são utilizados para análise de diversos aspectos da colite tais como: pesquisa de populações celulares, análises histológicas e análises fenotípicas entre outras.

\section{- Slc11a1 (Nramp1)}

O gene Scll1al, também conhecido como Nrampl (Natural Resistance Associated Macrophage Protein), localizado no cromossomo 1, foi descoberto através de posicionamento clonal, dentro do locus associado à resistência natural contra a infecção por S. typhimurium, L. donovani e várias espécies de micobactérias, incluindo 
M. bovis e M. lepraemurium, por isso também chamado locus Bcg, Lsh ou Ity (Vidal et al, 1993; Barton; Whitehead; Blackwell, 1995; Blackwell; Searle, 1999; WesslingResnick, 2015).

O gene Sclllal codifica uma proteína de membrana integral, de 90-100 kDa, hidrofóbica, que possui 12 domínios de membrana (TM) com um sítio de transporte conservado e uma região citoplasmática N-terminal que codifica um domínio de ligação SH3 rico em Pro/Ser (Vidal et al, 1993; Barton; Whitehead; Blackwell, 1995; Canonne-Hergaux et al, 1999; Vidal et al, 1996). Estudos mostraram que essa proteína possui uma estrutura secundária e terciária muito similar a canais de $\mathrm{K}^{+}$sendo altamente glicosilada e fosforilada em macrófagos (Blackwell; Searle, 1999; Vidal et al, 1996)

A proteína Scl11a1 localiza-se em lisossomos/endossomos tardios sendo encontrada em células de origem mielóides maduras (monócitos/macrófagos), granulócitos, células dendríticas e também em linfócitos (Archer, 2015; Govoni et al, 1997; Mulero et al, 2002; Valdez et al, 2008; Wessling-Resnick, 2015). É um transportador de cátions $\left(\mathrm{Fe}^{2+}, \mathrm{Zn}^{2+}\right.$, e $\left.\mathrm{Mn}^{2+}\right)$ do tipo simporte, onde o transporte ocorre em ambos os sentidos, sendo que a direção é dependente do $\mathrm{pH}$. Um dos mecanismos descritos é o transporte de ferro, que pode acontecer para dentro do fagossomo onde, sob baixo pH, a reação de Fenton $\left(\mathrm{H}_{2} \mathrm{O}_{2}+\mathrm{Fe}^{2+} \rightarrow \mathrm{Fe}^{3+}+\mathrm{OH}^{-}+\mathrm{OH}^{*}\right)$ favorece a geração de radicais de oxigênio (ROS) para matar microrganismos ou para fora do endossomo de modo a privar os microrganismos de um íon essencial. (Blackwell; Searle, 1999; Jabado et al, 2000; Wessling-Resnick, 2015).

O gene Sclllal tem um papel importante na imunidade inata e na defesa contra infecções. Embora os mecanismos ainda sejam desconhecidos, sabe-se que ele influencia a ativação de macrófagos exercendo uma gama de efeitos pleiotrópicos na função destas células, tais como a regulação de quimiocinas e citocinas, indução da enzima óxido nítrico sintetase (iNOS), expressão de moléculas classe II do complexo de histocompatibilidade principal (MHC), fator de necrose tumoral a (TNF $\alpha$ ), liberação de óxido nítrico (NO), fluxo de L-arginina, explosão oxidativa e tumoricida, bem como atividade antimicrobiana (Barton; Whitehead; Blackwell, 1995; Blackwell; Searle, 1999; Wojciechowski et al, 1999).

Este gene possui uma mutação pontual na região de leitura, G169D no quarto domínio da região transmembrana, que leva à substituição de aminoácidos não conservada de gly para asp na posição 169 e à formação de uma proteína não funcional. Essa mutação é responsável por um quadro de suscetibilidade a infecções. Frehel e 
colegas mostraram que em animais com o alelo suscetível $\operatorname{Nrampl}^{D 169}(S)$ os macrófagos apresentam uma maturação mais lenta dos lisossomos e uma menor taxa de fusão fagossomo-lisossomo do que os animais resistentes $\operatorname{Nrampl}^{G 169}(R)$. Acredita-se também que a proteína Nramp1 possa estar envolvida na sinalização intracelular (Vidal et al, 1996; Blackwell; Searle, 1999; Canonne-Hergaux et al, 1999)

Como foi citado anteriormente, os macrófagos possuem um papel importante na patogênese de IBD e como o gene Scl1lal exerce efeitos pleiotrópicos nessas células, influenciando na sua atividade, pode determinar a resistência ou a suscetibilidade à UC.

A associação deste gene com a ocorrência de IBD foi mostrada inicialmente por Kojima e colaboradores em populações japonesas e por Zaahl et. al em habitantes da África do Sul, onde polimorfismos no gene NRAMP parecem levar à predisposição à IBD (Archer, 2015; Sun; Zhang; Shi, 2016; Zaahl et al, 2006). Em camundongos foi visto por Jiang e colaboradores que o gene Sclllal também tem influência na colite induzida por DSS (Jiang et al., 2009). Portanto acredita-se que essa mutação possa ter um papel importante no desenvolvimento de UC.

\section{- Modelo animal}

Desde 2004, cientistas do mundo inteiro vêm utilizando, além das linhagens isogênicas como modelo de camundongos sensíveis à colite, animais geneticamente modificados em genes específicos reguladores do sistema imune no sentido de elucidar os mecanismos genéticos na patogênese da UC, bem como testar diferentes intervenções terapêuticas para inibir estrategicamente a expressão de genes específicos envolvidos na regulação da sensibilidade às doenças intestinais (Perse \&Cerar, 2012).

Esses modelos, de maneira geral, não refletem fielmente uma população geneticamente heterogênea como é a humana e, tratando-se de uma doença multifatorial, apresentam complexidades genéticas restritas para o entendimento amplo da doença. Neste sentido propomos a utilização de modelo de camundongos produzidos segundo um processo de seleção fenotípica artificial. 
Há anos o grupo de pesquisadores do Laboratório de Imunogenética do Instituto Butantan estuda a regulação genética das respostas imunológica específica e não específica representadas, respectivamente, pelos fenótipos de produção quantitativa de anticorpos e de desenvolvimento de reação inflamatória aguda por meio de experimentos de seleção fenotípica bidirecional, visando sempre a produção de linhagens de camundongos com características fenotípicas quantitativas opostas para estes dois caracteres imunológicos. Especificamente para a imunidade inata, foram obtidas linhagens com máxima (AIRmax) ou mínima (AIRmin) reatividade inflamatória aguda (AIR, do inglês: Acute Inflammatory Response) a corpo estranho, Biogel P100 (Ibanez et al, 1992).

As linhagens AIRmax e AIRmin foram obtidas por seleção fenotípica bidirecional a partir de uma população geneticamente heterogênea (F0) oriunda de cruzamentos equilibrados entre oito linhagens isogênicas (figura 1). Para selecionar os animais que apresentaram alta ou baixa reatividade inflamatória, foi injetado gel de poliacrilamida (Biogel) no tecido subcutâneo, substância não imunogênica e não biodegradável. A reação inflamatória produzida foi avaliada após 24 horas da injeção de Biogel, considerando o número total de leucócitos infiltrados e o teor de proteínas extravasadas (Biozzi et al, 1998; Ibanez et al, 1992).

Os camundongos que apresentaram alta ou baixa reatividade inflamatória foram acasalados seletivamente entre si para a produção das linhagens AIRmax e AIRmin, respectivamente. Estes acasalamentos foram realizados consecutivamente a cada geração de Seleção, sendo que o máximo de separação fenotípica entre as linhagens foi atingido ao redor de 20 gerações. Neste momento, os genes responsáveis pela regulação de máxima ou mínima resposta fixaram-se em homozigose nas respectivas linhagens, mantendo um fundo genético heterogêneo.

Ao longo do processo seletivo as diferenças fenotípicas entre as duas linhagens AIRmax e AIRmin aumentaram progressivamente. Por meio de cálculos de parâmetros genéticos, foi possível estimar que a regulação desse caráter deve ser operada pela interação de 9 a 12 loci gênicos independentes (Biozzi et al, 1998; Ibanez et al, 1992).

Estudos com os animais AIRmax e AIRmin foram realizados com o intuito de esclarecer a regulação genética operante em situações como: artrite induzida por pristane (Vigar et al, 2000), tumorigênese de pele (Biozzi et al, 1998; De Souza et al, 
2009), de pulmão (Maria et al, 2003) e de cólon (Di Pace et al, 2006), doenças infecciosas (Araujo et al, 1998; Borrego et al, 2006) e alterações na medula óssea (Katz et al, 2014; Katz et al, 2016)

Verificou-se também nestas linhagens um desequilíbrio de frequência entre os alelos de resistência $(\mathrm{R})$ e de susceptibilidade $(\mathrm{S})$ à infecção por S. typhimurium do gene Slc1lal (Nrampl). A frequência do alelo $\mathrm{S}$ na população inicial $\left(\mathrm{F}_{0}\right)$ era de $25 \%$ mas com a seleção ela mudou para $60 \%$ nos animais AIRmin e 9\% nos animais AIRmax, sendo que camundongos homozigotos para o alelo $S$ foi somente encontrado na linhagem AIRmin enquanto que os animais AIRmax não apresentaram este alelo em homozigose (Araujo et al, 1998).

Devido a essa diferença foi iniciada a produção de linhagens de camundongos homozigotos para os alelos $R$ e $S$ por meio de acasalamentos assistidos pelo genótipo, partindo das linhagens parentais AIRmax e AIRmin. Assim, foram produzidas as sublinhagens homozigotas para os alelos $\mathrm{R}$ e $\mathrm{S}$ do gene Slc1lal, denominadas $\operatorname{AIRmax}^{R R}, \operatorname{AIRmax}^{S S}, \operatorname{AIRmin}^{R R}$ e AIRmin ${ }^{S S}$, conforme exemplificado na figura 1.

Fig. 1 Seleção genética bidirecional

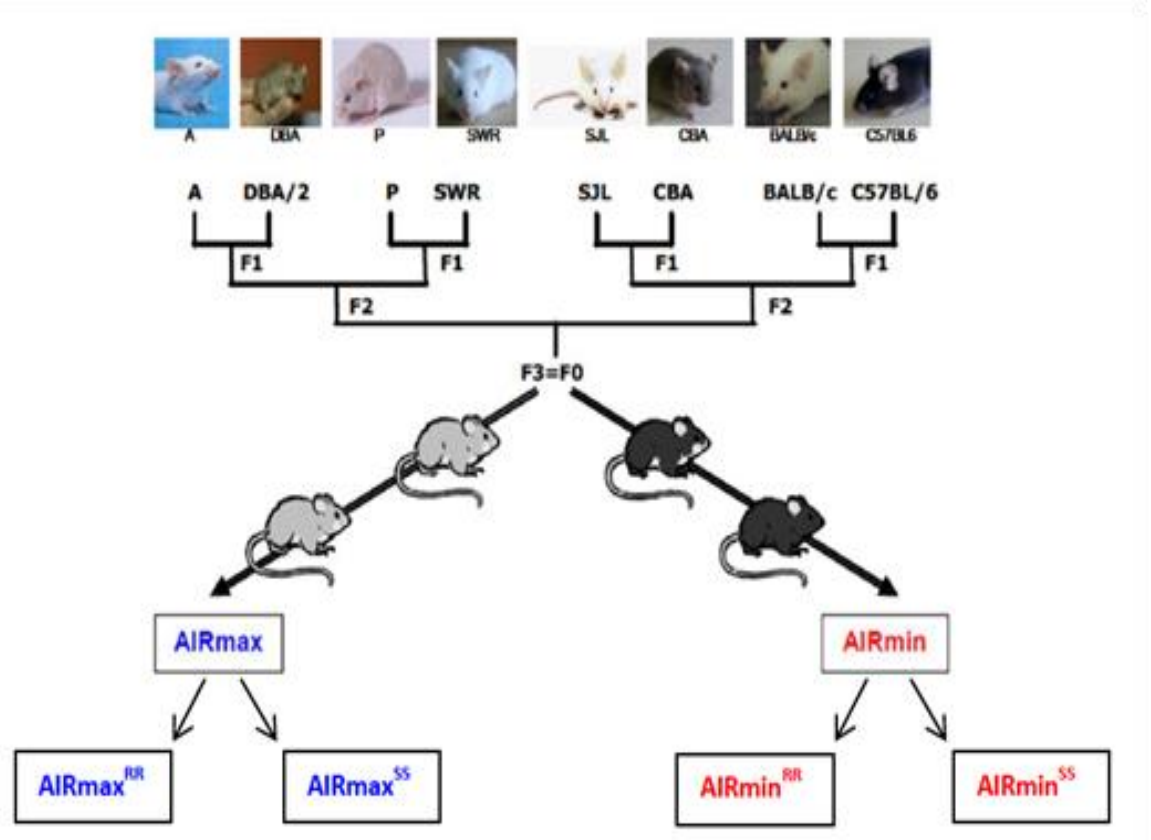

Seleção das linhagens AIRmax e AIRmin seguida da produção das sublinhagens R e S por genotipagem dos alelos do locus Slc1la1. 
Essas linhagens apresentaram diferenças com relação à resposta inflamatória demonstrando uma interação gênica entre os alelos do gene Slc1lal com aqueles selecionados para AIR. Foi observado que os animais AIRmin ${ }^{S S}$ foram extremamente sensíveis à infecção por S.typhimurium, com DL50 de 100 bactérias. Já os AIRmax ${ }^{\text {SS }}$ apresentaram comportamento de resistência indicando clara modulação do fundo genético fixado para máxima AIR sobre o fenótipo de sensibilidade que este alelo classicamente confere às linhagens isogênicas. Quanto à sensibilidade aos efeitos da endotoxina (LPS) a diferença de susceptibilidade está restrita à linhagem e não ao polimorfismo do gene Slc1lal, isto é, AIRmax mais sensível do que os AIRmin (Borrego et al, 2006).

Além das divergências na resposta contra S.typhimurium e LPS, esses animais também mostraram diferença na resposta na artrite reunatóide por Pristane (PIA- do inglês:Pristane-Induced Arthritis) (Peters, et al, 2007), nos níveis do componente C5 do sistema complemento, sendo os animais AIRmax ${ }^{R R}$ completamente deficientes (Amano et al, 2009), e no processo de cicatrização (De Franco et al, 2007).

Nesse contexto, propusemos avaliar a relação do gene Slc1lal com o desenvolvimento da UC por DSS comparativamente nas linhagens AIRmax e AIRmin homozigotas para os alelos $R R$ ou $S S$. Por meio da caracterização fenotípica dos aspectos clínicos, inflamatórios e estruturais do cólon, após o tratamento com DSS, permitiu propormos possíveis mecanismos operantes na UC relacionados ao polimorfismo do gene Scl11al. 


\section{OBJETIVOS}


O objetivo deste trabalho foi estudar a possível relação entre o gene Slc1 lal e o fenótipo de resistência ou suscetibilidade à UC induzida por DSS, utilizando as linhagens AIRmax e AIRmin homozigotas para os alelos $\mathrm{R}$ e $\mathrm{S}$ como modelo. Para tanto avaliamos:

-os aspectos clínicos como alterações do peso corpóreo e ocorrência de diarreia sanguinolenta ou não;

-variação do comprimento do cólon

-alterações da arquitetura do cólon decorrente do tratamento com DSS por meio de preparações histológicas focando na possível instalação de um processo inflamatório;

-a atividade de MPO como medida indireta da reação inflamatória;

-a produção de citocinas inflamatórias no cólon por Multiplex

-as populações celulares que possam estar modificadas localmente no cólon por meio de análise fenotípica por citometria de fluxo 


\section{Animais}

Foram utilizados camundongos machos das linhagens AIRmax e AIRmin com o alelo $S S$ e $R R$, AIRmax $^{R R}$ e $\operatorname{AIRmin}^{R R}$ e $\operatorname{AIRmax}^{S S}$ e AIRmin ${ }^{S S}$, com idade entre 2 e 3 meses mantidos no biotério do Laboratório de Imunogenética do Instituto Butantan. Os experimentos obedeceram aos preceitos do Comitê de Ética do Instituto Butantan (CEUAIB) protocolo $\mathrm{n}^{\circ}$ 1335/14.

\section{Indução da colite}

Os animais das quatro linhagens foram separados em dois grupos: tratados e controle, sendo submetidos a uma avaliação durante um período de 7 dias. $\mathrm{O}$ grupo tratado recebeu Dextran Sulfato de Sódio (MP - Biomedicals, LLC, France) (Di Pace et al, 2006) diluído a 2,5\% em água destilada em bebedouros para ingestão ad libitum durante 7 dias. Após esse período os animais foram eutanasiados e o cólon foi coletado. O grupo controle recebeu, simultaneamente ao grupo tratado, apenas água destilada em bebedouros para ingestão ad libitum e foram submetidos aos mesmos procedimentos.

Fig.2. Protocolo de indução da colite utilizando DSS-MP 2,5\%.

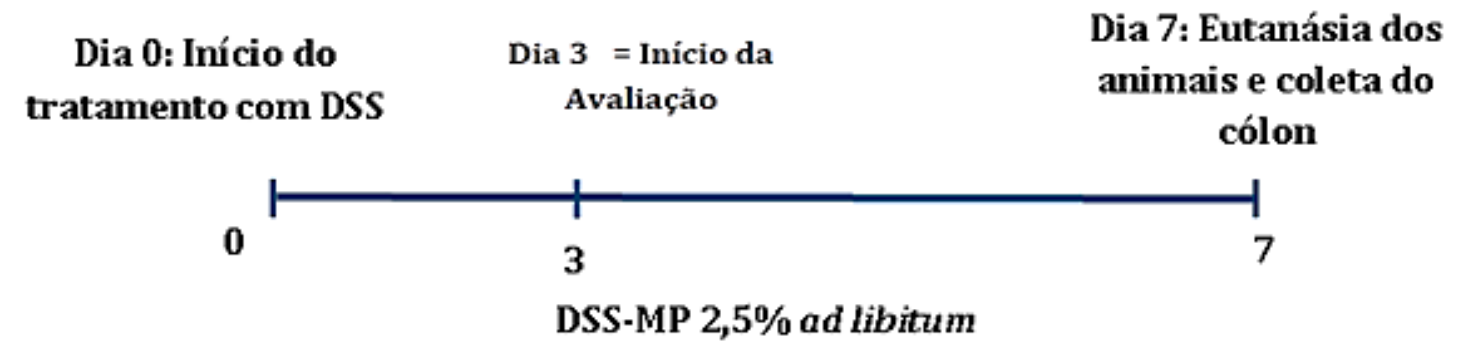

Figura de autoria própria 


\section{Análise fenotípica da Colite}

A caracterização do fenótipo da Colite foi realizada inicialmente pela avaliação do quadro clínico geral medido pelos parâmetros: alteração de peso corpóreo, consistência das fezes como indicação de diarreia e presença de sangue nas fezes diretamente ou no ânus do camundongo (Wirtz et al, 2007).

Os animais foram pesados antes do início do tratamento e diariamente a partir do terceiro dia e observados em relação à presença ou ausência de diarreia ou sangramento retal. Nesse período, foram determinados os valores diários de IAD calculados usando a fórmula:

IAD $=$ perda de peso corporal + escore de diarreia + escore de sangramento retal

As médias e o erro padrão foram calculados para os respectivos grupos.

Escores foram obtidos conforme tabela 1 a seguir:

Tabela1. Escores utilizados no cálculo do IAD baseado no trabalho de Wirtz et al, 2007

\begin{tabular}{cccc}
\hline Escores & Perda de Peso & Escores & \\
\hline D & Nenhuma & Ausente & Ausente \\
\hline $\mathbf{1}$ & $5-10 \%$ & Fezes semi-pastosas & $\begin{array}{l}\text { Sangue restrito ao ânus em pequena } \\
\text { quantidade e/ou filetes nas fezes }\end{array}$ \\
\hline
\end{tabular}

\begin{tabular}{|c|c|c|c|}
\hline 2 & $10-15 \%$ & Fezes pastosas & $\begin{array}{l}\text { Sangue nas fezes em quantidade } \\
\text { moderada e/ou além do ânus }\end{array}$ \\
\hline 3 & $15-20 \%$ & Fezes líquidas & $\begin{array}{l}\text { Sangue nas fezes e/ou além do ânus } \\
\text { em quantidade abundante }\end{array}$ \\
\hline
\end{tabular}


Após o período de 7 dias da avaliação clínica, os animais foram eutanasiados por deslocamento cervical, o cólon foi retirado, lavado em salina e seu comprimento e peso registrados. Em seguida, o tecido foi analisado quanto ao comprimento, características histológicas, atividade de MPO, produção de citocinas pro- e antiinflamatórias e caracterização celular por citometria de fluxo.

\section{Determinação da atividade da mieloperoxidase (MPO)}

Para a determinação da atividade de MPO, o segmento distal do cólon foi homogeneizado em Polytron (BRINCKMAN) com $1 \mathrm{~mL}$ de Brometo de Hexadeciltrimetilamônio (HTAB) 0,5\%, em EDTA (10 mM). Em seguida, as amostras foram centrifugadas a $10000 \mathrm{x}$ g, durante 10 minutos a $4^{\circ} \mathrm{C}$. O ensaio de MPO foi conduzido em $10 \mu 1$ do sobrenadante de cada amostra em placa de 96 poços adicionando $200 \mu 1$ de tampão substrato, constituído de: tampão fosfato 50mM, pH 6.0, peróxido de hidrogênio $0,1 \%$, orto-dianisidina $1,3 \%$ em $\mathrm{H}_{2} \mathrm{O}$. Após 5 minutos, a reação foi interrompida com a adição de $50 \mu \mathrm{l}$ de solução de azida sódica 1,3\% em $\mathrm{H}_{2} \mathrm{O}$. Os valores de atividade de MPO foram expressos pelo valor das absorbâncias, obtidas a $450 \mathrm{~nm}$ (por grama de tecido) em leitor de ELISA (Bio-Tek Instruments).

\section{Análise Histológica}

Segmentos distais do cólon foram obtidos e fixados em paraformaldeído $10 \%$ por $24 \mathrm{hs}$, seguido de armazenamento em etanol $70 \%$ até o processo de inclusão em parafina. As amostras foram incluídas em parafina e seccionadas a $5 \mu \mathrm{m}$ para coloração com Hematoxicilina e Eosina (HE). Os cortes foram analisados pelas patologistas Natalia Coelho Couto de A. Fernandes e Juliana Mariotti Guerra do Núcleo de Anatomia Patológica - Instituto Adolfo Lutz. Elas deram escores para os segmentos utilizando os parâmetros histológicos presentes em três grandes categorias de acordo com Erben e colaboradores (2014), conforme Tabela 2. 
Tabela 2. Escores utilizados na classificação dos parâmetros Histológicos por Erben et al, 2014

\begin{tabular}{|c|c|c|c|c|c|c|c|c|}
\hline \multicolumn{9}{|c|}{ Escores } \\
\hline Categoria & Infil & rado inflamatc & rio & & Arquitetura Te & cidual & Alteração & Epitelial \\
\hline Escores & Severidade & Extensão & $\begin{array}{c}\text { Tipo de } \\
\text { infiltrado }\end{array}$ & Erosão & $\begin{array}{c}\text { Tecido de } \\
\text { Granulação }\end{array}$ & $\begin{array}{c}\text { Edema de } \\
\text { Submucosa }\end{array}$ & Hiperplasia & $\begin{array}{l}\text { Perda/ } \\
\text { Necrose }\end{array}$ \\
\hline 1 & $\begin{array}{l}\text { Mínimo } \\
<10 \%\end{array}$ & Mucosa & $\begin{array}{c}\text { Linfo- } \\
\text { histiocitário }\end{array}$ & 1 & 1 & 1 & $\begin{array}{l}\text { Mínima } \\
<25 \%\end{array}$ & $\begin{array}{l}\text { Mínima } \\
<25 \%\end{array}$ \\
\hline 2 & $\begin{array}{l}\text { Discreto } \\
10-25 \%\end{array}$ & $\begin{array}{l}\text { Mucosa e } \\
\text { Submucosa }\end{array}$ & Misto & 2 & 2 & 2 & $\begin{array}{l}\text { Discreta } \\
25-35 \%\end{array}$ & $\begin{array}{l}\text { Discreta } \\
25-35 \%\end{array}$ \\
\hline 3 & $\begin{array}{l}\text { Moderado } \\
26-50 \%\end{array}$ & Transmural & Heterofílico & 3 & 3 & 3 & $\begin{array}{l}\text { Moderada } \\
36-50 \%\end{array}$ & $\begin{array}{l}\text { Moderada } \\
36-50 \%\end{array}$ \\
\hline 4 & $\begin{array}{c}\text { Marcante } \\
>51 \%\end{array}$ & - & & 4 & 4 & 4 & $\begin{array}{l}\text { Marcante } \\
>51 \%\end{array}$ & $\begin{array}{l}\text { Marcante } \\
>51 \%\end{array}$ \\
\hline
\end{tabular}

\section{Expressão gênica (RT-PCR)}

\section{Extração e purificação de RNA (RNAspin Mini Kit Healthcare)}

Para a extração de RNA foi utilizado um fragmento de $30 \mathrm{mg}$ do segmento distal do cólon, triturado em equipamento TissueLyser LT (Qiagen), utilizando tubos eppendorf de $2 \mathrm{~mL}$ contendo 1 esfera de aço inoxidável ( $5 \mathrm{~mm}$ de diâmetro médio) e incubada por 15 minutos em gelo seco. Os tubos foram inseridos no adaptador do TissueLyser (mantido a $15-25^{\circ} \mathrm{C}$ ) e incubados à temperatura ambiente durante 2 minutos. Após a adição de $1 \mathrm{ml}$ de tampão de lise (GE Healthcare) o TissueLyser operou por 4 minutos a $50 \mathrm{~Hz}$ para homogeneização completa do tecido e as amostras foram colocadas em um mini filtro RNAspin e centrifugadas por 1 minuto a $13.000 \mathrm{x}$ g. Após a extração, a purificação foi realizada seguindo as instruções do fabricante do kit GE Healthcare UK Limited.

\section{Real Time PCR (RT-PCR)}

A partir do RNA extraído, $1 \mu \mathrm{g}$ foi usado para sintetizar cDNA por transcrição reversa usando First Strand cDNA Synthesis Kit (Roche, Basiléia, Suíça) com uma mistura 1: 1 de oligo (dT) e oligonucleotídeos hexâmeros aleatórios, de acordo com as instruções do fabricante. Foi utilizado $5 \mu \mathrm{L}$ do cDNA na diluição 1:10, a seguir foram adicionados $10 \mu \mathrm{L}$ de Fast SYBR Green Master Mix (2x) e $300 \mu \mathrm{M}$ dos primers sensoriais e antisense descritos abaixo em um volume final de reação de $20 \mu \mathrm{L}$. Os 
ensaios foram realizados em 4 repetições, incluindo a análise da expressão gênica constitutiva de RPS29 (Proteína Ribossomal S29), Ppia (Ciclofilina) e os genes Il-1 , Il-6, Il-10, Il-17, Tnf- $\alpha$,Inf- $\gamma$ Mcp-1, Gm-csf, Mip-1 $\alpha$.

\begin{tabular}{|c|c|c|}
\hline Gene & Primer Foward & Primer Reverse \\
\hline Ppia(Ciclo) & 5'- AGCGTTTTGGGTCCAGGAAT-3' & 3'-AAATGCCCGCAAGTCAAAAG-5' \\
\hline RPS29 & 5'-TCTACTGGAGTCACCCACGGAAGT-3' & 3'-GTCAGTCGAATCCATTCAAGGTCGC-5' \\
\hline$I l-1 \beta$ & 5'-TTGACGGACCCCAAAAGATG-3' & 3'-AGAAGGTGCTCATGTCCTGA-5' \\
\hline Il-6 & 5'-GTTCTCTGGGAAATCGTGGA-3' & 3'-TGTACTCCAGGTAGCTATGG-5' \\
\hline Il-10 & 5'-GCTGGACAACATACTGCTAACC3' & 3'-CCCAAGTAACCCTTAAAGTCCTG-5' \\
\hline Il-17 & 5'-TGAACCTCCTGGATGACATG-3' & 3'-GTGTTTCACAGTCCGTTTCC-5' \\
\hline $\operatorname{Tnf}$ & 5'-TCTCATCAGTTCTATGGCCC-3' & 3'-GGGAGTAGACAAGGTACAAC-5' \\
\hline $\operatorname{Inf\gamma }$ & 5'-GCTCTGAGACAATGAACGCT-3' & 3'-AAAGAGATAATCTGGCTCTGC-5' \\
\hline$M C P-1$ & 5'-GCCTGCTGTTCACAGTTGC-3' & 3'-TCATTGGGATCATCTTGCTG-5' \\
\hline$G M-C S F$ & 5'-TGAACCTCCTGGATGACATG-3' & 3'-GTGTTTCACAGTCCGTTTCC-5' \\
\hline Mip-1 $1 \alpha$ & 5'-GGTCTCCACCACTGCCCTTCG-3' & 3'-GGTGGCAGGAATGTTCGGCTC-5' \\
\hline
\end{tabular}

As reações foram incubadas no termociclador PT-200 (MJ Research, Inc. Whatertown, MA, EUA) e inicialmente submetidas a uma fase de ativação da enzima polimerase a $95^{\circ} \mathrm{C}$ durante $15 \mathrm{~min}$. ("Hot Start"). As sequências alvo foram amplificadas com 50 ciclos consistindo em etapas sucessivas de desnaturação (95 durante 20 segundos), emparelhamento (55 durante 20 segundos) e extensão (72 durante $1 \mathrm{~min}$ ). A detecção de fluorescência de SYBR Green incorporada no material de cadeia dupla foi realizada na etapa de extensão no aparelho StepOnePlus (A\&B Applied Biosystem). Após a etapa de amplificação, o produto da reação foi submetido a um estágio de fusão onde a temperatura variou de 55 a $99^{\circ} \mathrm{C}$ e a fluorescência da reação foi adquirida a cada $1{ }^{\circ} \mathrm{C}$, registrando a temperatura na qual a dissociação ou desnaturação da fita dupla do material amplificado ocorreu. Os dados foram analisados pelo programa "Opticon Monitor Analysis Software 2.03" 


\section{Dosagem de Citocinas por Multiplex}

\section{Extração proteica}

Para avaliar a produção de citocinas pró e anti-inflamatórias, o segmento distal foi homogeneizado e as proteínas extraídas seguindo protocolo de extração utilizando o TissueLyser.

Para este fim, $30 \mathrm{mg}$ do segmento distal foram transferidos para préarrefecimento a $4^{\circ} \mathrm{C}$ em tubos de microcentrífuga de $2 \mathrm{ml}$ contendo 1 esfera de aço inoxidável (5 mm de diâmetro médio) e incubados durante 15 minutos em gelo seco. Os tubos foram então inseridos no adaptador TissueLyser (mantido a $15-25^{\circ} \mathrm{C}$ ) e incubados à temperatura ambiente durante 2 minutos onde foi adicionado $1 \mathrm{ml}$ de tampão de lise.

O tampão de lise utilizado foi o meio RIPA consistindo em: Hidroximetilaminometano (Tris) 50Mm; $\mathrm{NaCl}$ 150Mm; EDTA 1Mm pH 8,0; Triton X-100 1\%; SDS - Dodecil Sulfato de Sódio e os comprimidos do coquetel de inibição de proteaseEDTA-Free(SIGMA-S8830-2TAB). O TissueLyser operou por 4 minutos a $50 \mathrm{~Hz}$ para homogeneização completa do tecido. A amostra foi então centrifugada a $1000 \mathrm{x} \mathrm{g}$ durante 10 minutos e o sobrenadante foi armazenado a $-80^{\circ} \mathrm{C}$.

\section{Determinação do nível de citocinas por Multiplex}

Para a avaliação da produção das citocinas IL-1 $\beta$, IL-6, IL-10,IL-17 TNF- $\alpha$, INF- $\gamma$; quimiocinas MCP-1 e MIP-1 $\alpha$ e fatores de crescimento G-CSF, GM-CSF e MCSF produzidas localmente, foi utilizado o lisado de um fragmento do terço distal do cólon por meio do teste Multiplex.

A tecnologia Multiplex MILLIPLEX ${ }^{\circledR}$ MAP é baseada na Luminex ${ }^{\circledR}$ xMAP $^{\circledR}$ que consiste em um processo que marca microesferas de poliestireno com dois fluoróforos. Por meio da utilização de concentrações precisas destas substâncias, podem ser criados até 100 conjuntos diferentes de microesferas, cada uma delas com uma assinatura baseada em um código de cores, que podem ser identificadas pelo instrumento Bioplex.

Para tanto, as amostras foram previamente centrifugadas e mantidas a temperatura ambiente (TA) antes de iniciar o ensaio. Primeiramente, a placa foi lavada com $200 \mu \mathrm{L}$ de tampão de lavagem por poço e mantida sob agitação por 10 min a TA e em seguida o conteúdo foi dispensando pela inversão da placa magnética. Foram 
adicionados $25 \mu \mathrm{L}$ de cada padrão e controles nos poços apropriados segundo a indicação do fabricante. Adicionamos $25 \mu \mathrm{L}$ de amostras não diluídas (puro) nos poços apropriados. Logo após foram acrescentados $25 \mu \mathrm{L}$ das microesferas em cada poço. As placas foram cuidadosamente seladas e incubadas overnight. No dia seguinte, o conteúdo foi cuidadosamente removido pela inversão da placa e realizado duas lavagens com $200 \mu \mathrm{L}$ de tampão. Adicionamos $25 \mu \mathrm{L}$ dos anticorpos/poço de detecção e realizado uma incubação por $1 \mathrm{~h}$. Acrescentamos $25 \mu \mathrm{L}$ /poço de estreptoavidina PE e incubamos por adicionais 30 min. $\mathrm{O}$ conteúdo da placa foi removido e em seguida foram realizadas duas lavagens. Adicionamos $150 \mu \mathrm{L}$ de "Sheath fluid" e a leitura foi realizada no aparelho Bioplex seguindo as instruções do fabricante.

\section{Análise fenotípica por citometria de fluxo}

Células viáveis foram isoladas de diferentes segmentos do cólon através do método utilizado por Gasteiger (Gasteiger et al, 2015) e numeradas em câmara hemocitométrica de Malassez. Uma alíquota de $100 \mu \mathrm{L}$ de uma suspensão celular a $1 \times 10^{6}$ células/mL foi incubada com anticorpos monoclonais dirigidos contra: CD11b (clone M1/70), Gr1 (clone RB6-8C5), CD4 (clone RM4-5), CD8 (clone 53-6.7),CD45 (clone 30-F11), MHCII (clone M5/114.15.2), F4/80 (clone BM8) e IL-10 (clone SXC1). Como controle foi utilizado células não marcadas. Todos os anticorpos são originados da BD Biosciences Pharmigen (BD Biosciences Pharmigen, Franklin Lakes, NJ, USA). Foi considerado o registro de 50000 células, utilizando FACSCantoII e analisado pelo programa FlowJo (Tree Star).

\section{Análise estatística}

As diferenças entre as médias foram calculadas pelo teste ANOVA seguido pelo teste de Turkey para a comparação entre os grupos. Consideramos significativos os valores de $p$ inferiores a 0,05 , bicaudal. Os dados foram analisados por meio do programa GraphPadPrism 4.0 (GraphPad Software, San Diego, CA,). 
Após a indução da colite por DSS, os animais foram avaliados a partir do terceiro dia, com base na perda de peso, consistência das fezes e presença de sangramento (fezes ou ânus), e no sétimo dia foram eutanasiados para a retirada do cólon, o qual foi utilizado diferentes fragmentos do segmento distal. Foram utilizadas como abordagens: caracterização fenotípica da doença através do IAD, medida do comprimento do cólon, avaliação histológica e avaliação da inflamação por meio da medida da MPO, citocinas e fenotipagem das células do tecido.

\section{Fenótipo da Colite}

Os parâmetros utilizados para caracterização do IAD foram: perda de peso, sangramento nas fezes e/ou ânus e consistência das fezes. A cada um deles foi dado um escore conforme tabela 1 em Metodologia e o escore final foi o resultado da somatória dos vários parâmetros considerados. Assim os animais tratados com DSS das quatro linhagens tiveram seus escores registrados durante 5 dias consecutivos.

De acordo com a figura 3, os animais que apresentaram um maior índice de IAD foram os AIRmin ${ }^{S S}$, caracterizado por uma perda de peso acentuada (Fig.4) e significativo sangramento. As demais linhagens apresentaram os mesmos sintomas, mas de forma menos agressiva. O grupo AIRmax também apresentou sintomas, porém de forma muito branda, independente da presença dos alelos $R$ ou $S$. Este resultado infere que o alelo $S$ confere um fenótipo de suscetibilidade à colite, mas ocorrendo apenas em um background de baixa resposta inflamatória. 
Fig.3. Fenótipo da colite

\section{A}

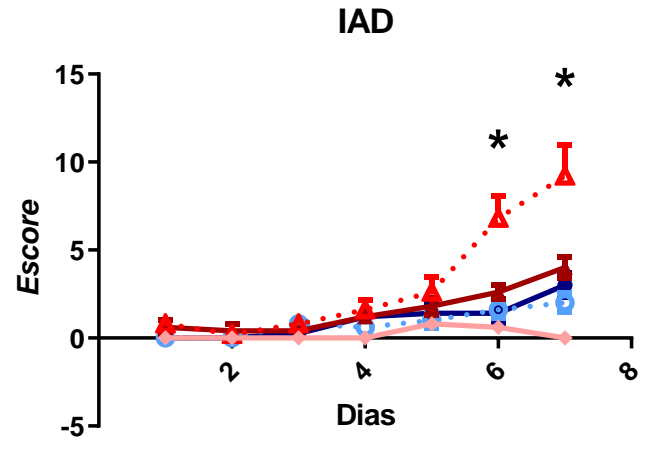

B

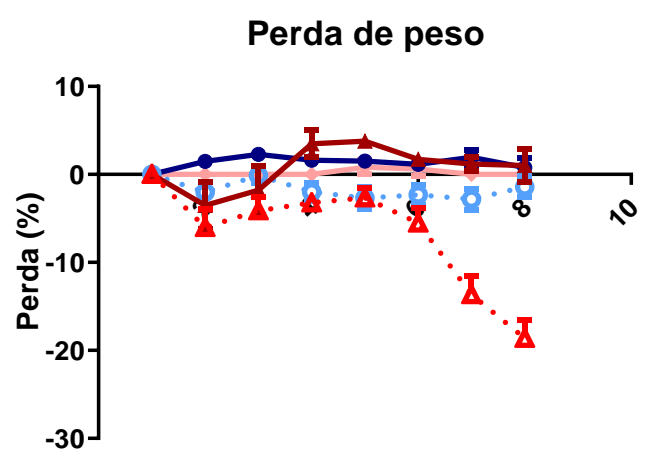

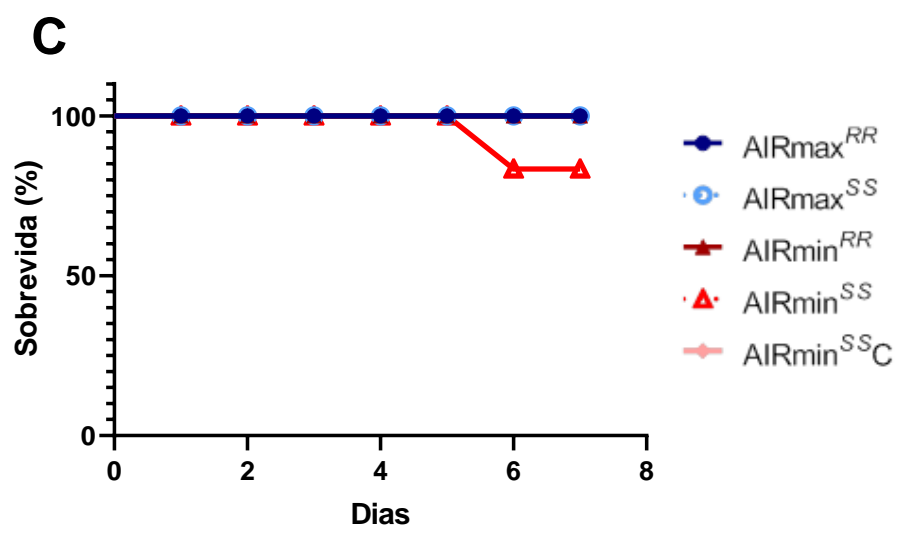

Grupos de camundongos das linhagens AIRmax ${ }^{R R}$, AIRmax ${ }^{S S}, \operatorname{AIRmin}^{R R}$ e $\operatorname{AIRmin}^{S S}$ foram avaliados, do $3^{\circ}$ ao $7^{\circ}$ dia, em relação IAD (A), com relação a porcentagem de perda de peso $(\mathbf{B})$ e mortalidade $(\mathbf{C})$ durante 7 dias de tratamento com DSS na concentração de 2,5\%(n=5) ou água $(n=5)$. Os dados estão expressos como média \pm erro padrão e as diferenças entre as médias são significativas para $p<0,05$ (ANOVA) * AIRmin $^{S S}$ x AIRmax ${ }^{R R}$ AIRmax $^{S S} \operatorname{AIRmin}^{R R}$.

Outra característica avaliada foi a variação do comprimento do cólon considerado da extremidade distal (reto) até o início do ceco. Os resultados apresentados na figura 4 mostram que em todos os grupos, exceto AIRmax ${ }^{\mathrm{SS}}$, o comprimento do cólon diminuiu significativamente quando comparado aos respectivos controles. Entre os grupos tratados com DSS foi observado que o grupo AIRmin ${ }^{S S}$ apresentou a maior diminuição de comprimento, o que evidencia a severidade da doença nesta linhagem, corroborando os dados de fenótipo de IAD. 
Fig.4. Comprimento do cólon.

\section{Comprimento do cólon}

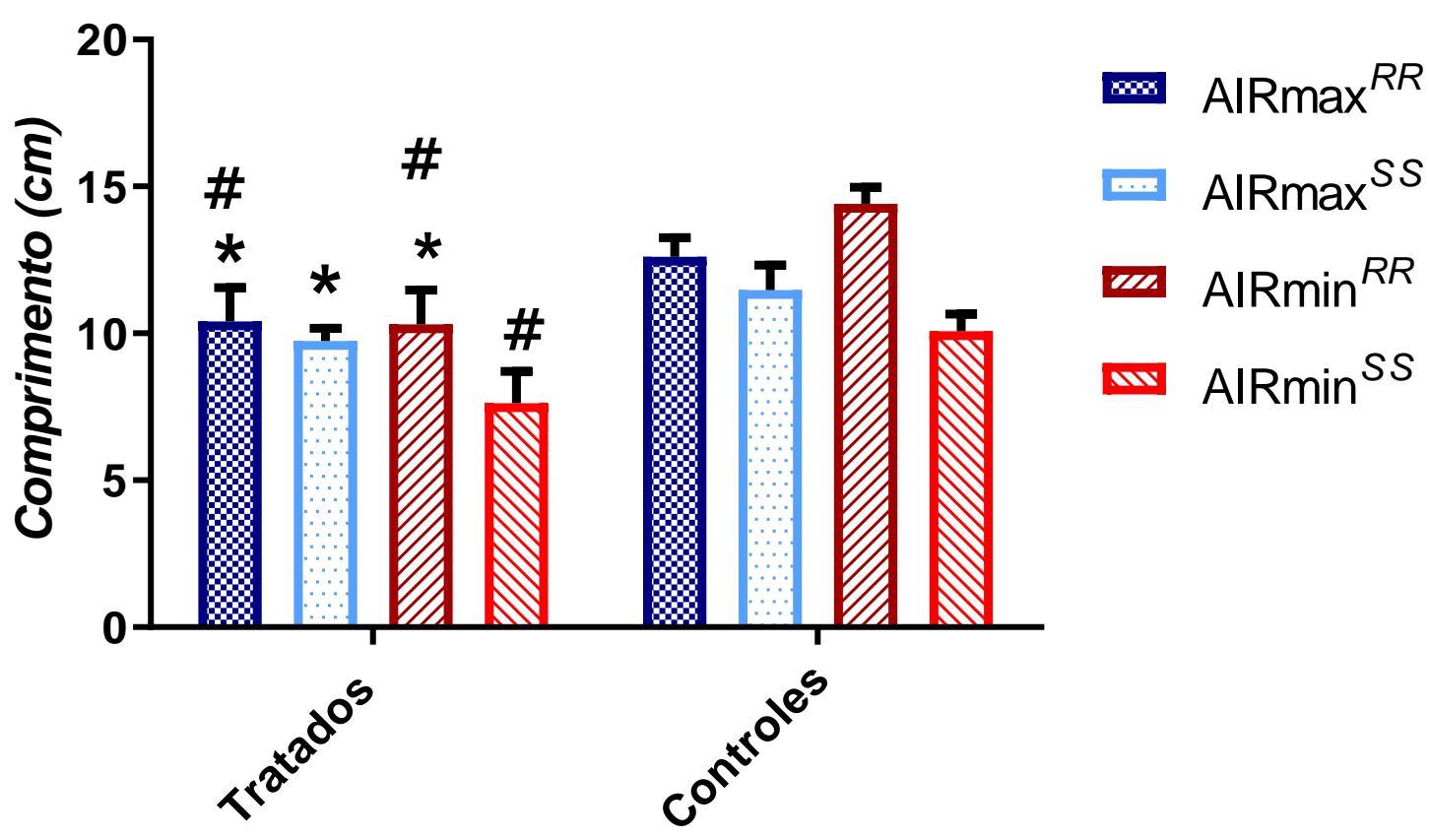

Animais das linhagens AIRmax ${ }^{R R}$ AIRmax ${ }^{S S}$ AIRmin ${ }^{R R}$ e AIRmin ${ }^{S S}$ tratados com DSS na concentração de 2,5\% $(n=5)$ e animais controles $(n=5)$ foram avaliados com relação a diminuição de comprimento do cólon. Os dados estão expressos como média \pm erro padrão e as diferenças entre as médias são significativas para $p<0,05$ (ANOVA) * AIRmin ${ }^{S S} \mathrm{x}$ AIRmax ${ }^{R R}$ AIRmax ${ }^{S S}$ AIRmin ${ }^{R R}$ e \# Tratados $\mathrm{x}$ Controles. 


\section{Quantificação da Mieloperoxidase (MPO)}

Para verificar se os parâmetros da colite induzida por DSS (IAD) observado está relacionado com a inflamação, foi medida a atividade enzimática da mieloperoxidase no segmento distal do colón no $7^{\circ}$ dia do tratamento. Foi observado que os grupos $\operatorname{AIRmax}^{R R}$ e AIRmin $^{R R}$ tiveram um aumento da atividade de MPO enquanto que os grupos AIRmax $^{S S}$ e $\mathrm{AIRmin}^{S S}$ não apresentaram aumento ou não o mantiveram até o final do tratamento (Fig. 5). Isso indica que o alelo $S$ pode interferir com a atividade desta enzima e consequentemente com a inflamação exclusiva por neutrófilos.

Fig.5. Atividade de mieloperoxidase (MPO).

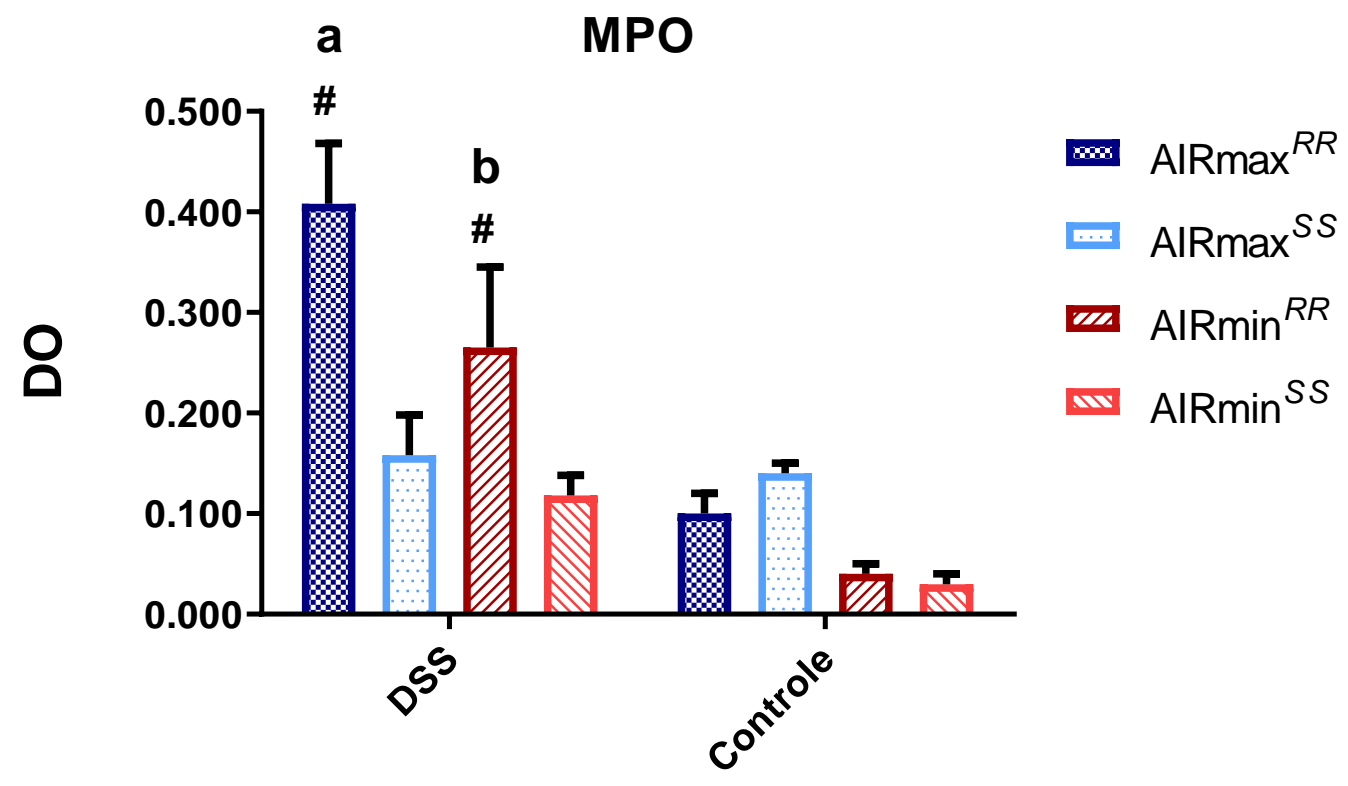

Animais dos grupos AIRmax ${ }^{R R}$, AIRmax ${ }^{S S}, \operatorname{AIRmin}^{R R}$ e AIRmin ${ }^{S S}$ tratados com DSS na concentração de $2,5 \%(n=5)$ e animais controle que receberam água $(n=5)$ foram analisados com relação a atividade de Mieloperoxidase no segmento distal. Os dados estão expressos como média \pm erro padrão e as diferenças entre as médias são significativas para $p<0,05$ (ANOVA) a: $\operatorname{AIRmax}^{R R} \mathrm{x} \operatorname{AIRmax}^{S S} \mathbf{b}$ : $\operatorname{AIRmin}^{R R} \mathrm{x}$ AIRmin $^{S S}$ e \#: Tratado x Controle. 


\section{Análise Histológica}

Para observar o grau de severidade da doença, realizamos análise histológica dos cólons obtidos no $7^{\circ}$ dia de tratamento com DSS. Um fragmento do segmento distal do cólon foi utilizado para a preparação das lâminas que foram coradas com Hematoxilina/Eosina $(\mathrm{H} \& \mathrm{E})$ para análise por patologistas especializados. A análise obedeceu o critério sugerido por Erben (2014) que estabeleceu escores para representar o nível da inflamação, arquitetura tecidual e alteração do epitélio (Tabela 2).

Na figura 7 está representada uma fotomicrografia de cada linhagem para os dois grupos: não tratados (A, B, C e D) e tratados com DSS (E, F, G e H). Verificamos que, apesar de um baixo IAD na análise clínica, o grupo AIRmax ${ }^{R R}$ apresentou um grande infiltrado infamatório e também danos à estrutura do cólon. No entanto, a barreira epitelial não sofreu muitos danos (seta), o que pode ser a causa de seus sintomas clínicos serem mais brandos do que os demais grupos (Fig.6E).

O grupo AIRmax ${ }^{S S}$ mostrou o menor nível de IAD e na histologia, a arquitetura do cólon se manteve relativamente intacta assim como a barreira epitelial (seta), embora tenha a presença de um infiltrado inflamatório (Fig.6F).

O grupo AIRmin ${ }^{R R}$ apresentou o segundo maior IAD, no entanto o perfil histológico apresentou um baixo infiltrado inflamatório e a arquitetura do cólon, embora tenha sofrido danos, se manteve pouco prejudicada. Já a barreira epitelial foi severamente danificada (seta) (Fig. 6G).

O grupo AIRmin ${ }^{S S}$, como verificado na Figura 1, apresentou o maior IAD na avaliação clínica, indicando maior sensibilidade ao tratamento por DSS. Comparando com o perfil obtido com a análise histológica observamos que esse grupo apresentou um alto infiltrado inflamatório, uma arquitetura do colón severamente comprometida e a barreira epitelial altamente danificada (seta) (Fig.6H).

As análises por escores, representados pelas medianas, mostraram uma diferença entre os grupos em relação ao infiltrado inflamatório, à destruição da arquitetura da tecidual e às alterações epiteliais. Embora todos tenham apresentado um infiltrado inflamatório misto, que nos casos mais graves afetou até a submucosa, o grau de lesão 
na arquitetura do epitélio variou entre os grupos, sendo que os animais AIRmin ${ }^{S S}$ foram os mais afetados (Tabela 3).

Fig.6. Fotomicrografias das porções distais do Cólon obtidas dos animais AIRmaxRR, AIRmaxSS, AIRminRR e AIRminSS aos 7 dias após tratamento com DSS a 2,5\% ou Água.

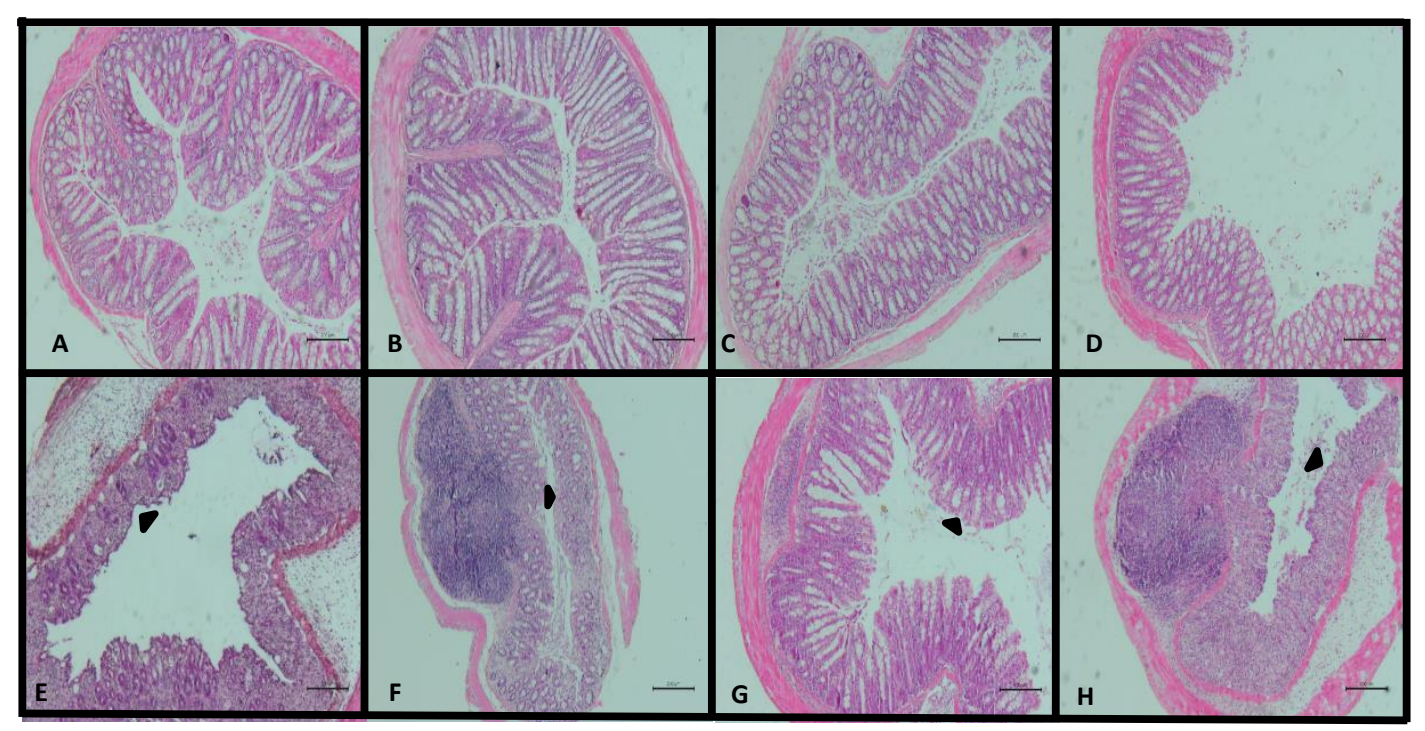

Animais $\operatorname{AIRmax}^{R R}(\mathrm{~A}), \mathrm{AIRmax}^{S S}(\mathrm{~B}), \operatorname{AIRmin}^{R R}(\mathrm{C})$ e $\mathrm{AIRmin}^{S S}$ (D) representam os grupos tratados com água. Animais $\operatorname{AIRmax}^{R R}(\mathrm{E}), \operatorname{AIRmax}^{S S}(\mathrm{~F}), \operatorname{AIRmin}^{R R}(\mathrm{G})$ e $\operatorname{AIRmin}^{S S}(\mathrm{H})$ foram tratados com 2,5\% de DSS ad libitum. As setas indicam destruição epitelial. Coloração H\&E. Escala $200 \mu$ m.

Tabela 3. Mediana dos escores dos animais dos grupos AIRmax ${ }^{R R}$, AIRmax ${ }^{S S}$ AIRmin ${ }^{R R}$ AIRmin ${ }^{S S}$ segundo os parâmetros da Tabela 1 .

Infiltrado inflamatório

Parâmetros Severidade Extensão Tipo de

\section{Arquitetura tecidual}

Tecido de Edema de Granulação Submucosa

\section{Alteração epitelial}

Perda glandular/Necrose

\begin{tabular}{lcccccccc}
\hline AIRmax $^{R R}$ & 2 & 2 & 2 & 0,5 & 1,5 & 2 & 0 & 1,5 \\
\hline AIRmin $^{R R}$ & 1,5 & 1,5 & 1,5 & 0 & 1 & 0 & 0,5 & 0 \\
\hline AIRmax $^{S S}$ & 1,5 & 1 & 2 & 0 & 0,5 & 1 & 0 & 2 \\
\hline AlRmin & 2 & 2 & 2 & 2 & 2 & 1 & 0 & 2 \\
\hline
\end{tabular}


Na Figura 7 estão representados as médias dos parâmetros considerados na análise histológica: inflamação (A), alterações no tecido e epitélio (B e C). A análise desses parâmetros mostrou que apesar de todos os animas apresentarem um aumento equivalente de inflamação com escore ao redor de 2,5, os animais $\operatorname{AIRmin}^{S S}$ desenvolvem mais alterações na arquitetura tecidual ou epitelial em relação às demais linhagens, especialmente erosão, o que demonstra a maior sensibilidade desse grupo ao DSS. A média do grupo controle engloba os animais das quatro linhagens por não apresentarem alterações significativas conforme visto nos cortes apresentados na figura 6.

Fig.7. Parâmetros de Histologia
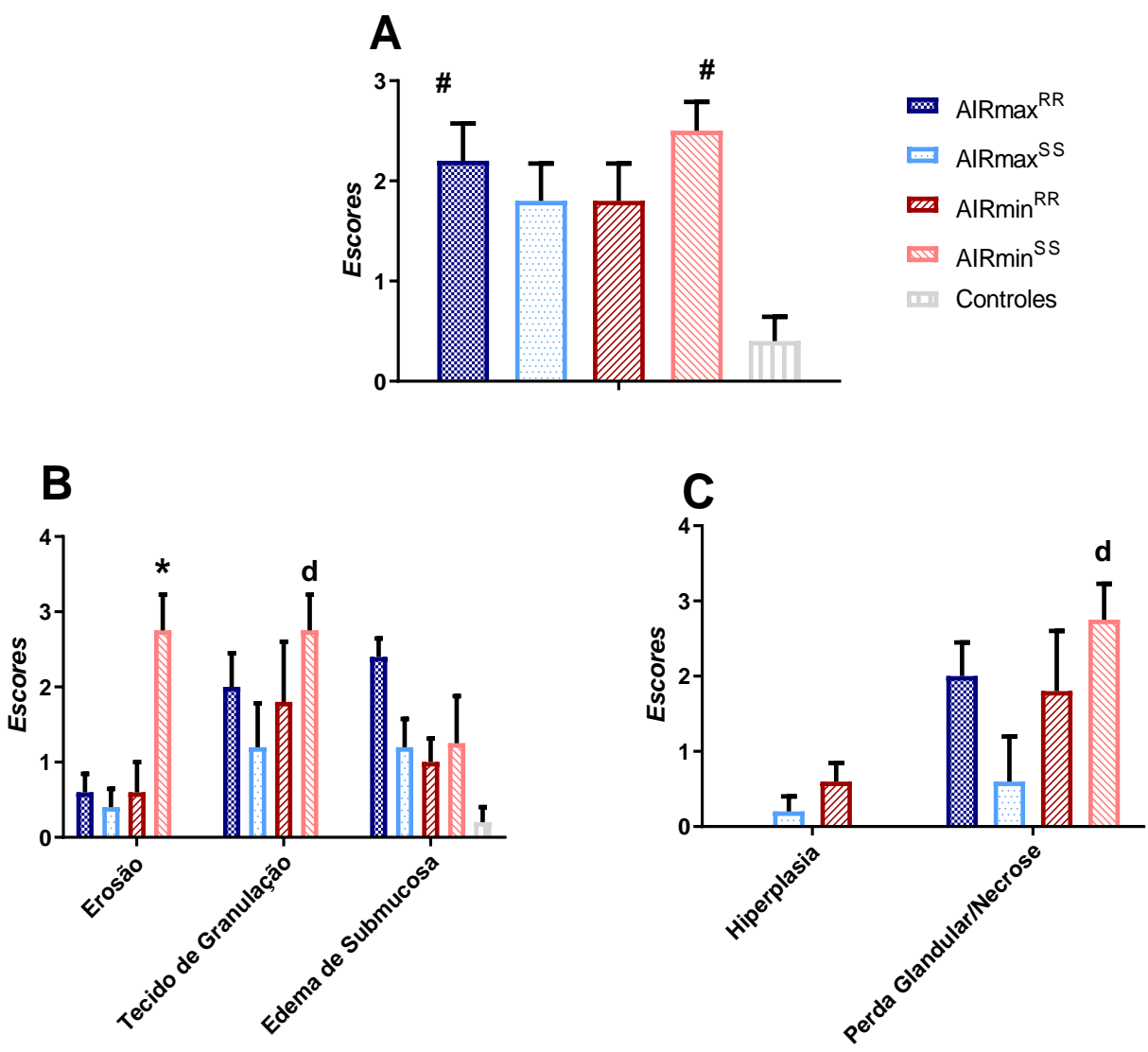

Média dos escores utilizados para avaliar os cortes histológicos de animais das linhagens AIRmax ${ }^{R R}$, $\mathrm{AIRmax}^{S S}, \mathrm{AIRmin}^{R R}$ e AIRmin ${ }^{S S}$ tratados com DSS na concentração de 2,5\% $(n=5)$ e animais controle que receberam água $(n=5)$. (A) Intensidade da Reação Inflamatória. (B) Alterações na arquitetura tecidual e (C) alteração epitelial. Os dados estão expressos como média \pm erro padrão e as diferenças entre as médias são significativas para $p<0,05$ (ANOVA). $*{ }^{*} \operatorname{IIRmin}^{S S} \times \operatorname{AIRmax}^{R R} \operatorname{AIRmax}^{S S} \operatorname{AIRmin}^{R R}$; d: AIRmax $^{S S}$ x AIRmin ${ }^{S S}$ \#: Tratado x Controle. 


\section{Caracterização das populações celulares no cólon}

Com a finalidade de caracterizarmos as populações celulares presentes no cólon dos camundongos e avaliarmos as possíveis diferenças intra- ou interlinhagens, células foram obtidas do segmento distal do cólon de animais tratados ou não com DSS 2,5\% no $7^{\circ}$ dia de tratamento e marcadas com anticorpos específicos, cujas combinações são usadas para caracterizar fenotipicamente as diferentes populações celulares (imunofenotipagem). Os grupos tratados foram compostos de 5 animais de cada linhagem que receberam 2,5\% de DSS e 3 animais de cada linhagem como controles que receberam apenas água.

Apresentamos na Figura 8 o número total de células (células/mL) obtidas do cólon para cada linhagem estudada. Verificamos que o rendimento de extração foi alto e uniforme, onde todos os grupos, incluindo os controles, atingiram a ordem de 2 a $3 \times 10^{6}$ células $/ \mathrm{mL}$, independentemente do tratamento.

Fig.8. Número total de células no segmento distal do cólon

\section{Total}

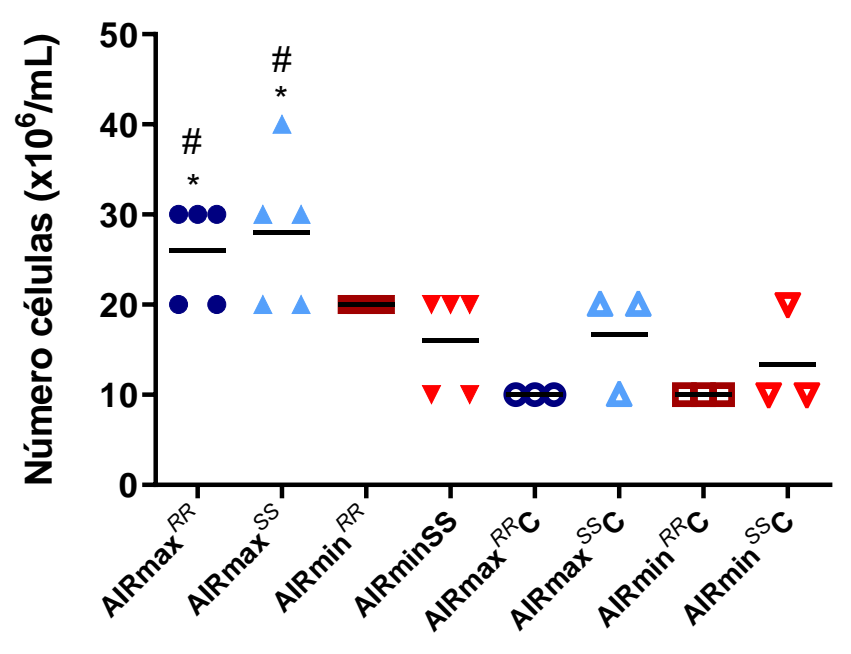

Número total de células extraídas do cólon no $7^{\circ}$ dia do tratamento com DSS 2,5\% ou água de 5 animais de cada grupo AIRmax ${ }^{R R}$, AIRmax ${ }^{S S}$, AIRmin ${ }^{R R}$, AIRmin ${ }^{S S}$. \# diferença em relação aos controles. *Diferença entre AIRmax e AIRmin. Os resultados estão expressos com os valores individuais e média. $\mathrm{O}$ teste estatístico, ANOVA, considerou significante quando $\mathrm{p}<0,05$, bicaudal. 
Para caracterizar as populações celulares presentes no cólon após digestão dos segmentos por colagenase foi utilizada a seguinte estratégia de marcação: população granulocítica $\left(\mathrm{CD} 11 \mathrm{~b}^{+} \mathrm{GR} 1^{+}\right)$, linfócitos TCD4 ou TCD8 na população de $\mathrm{CD} 45^{+}$ $\left(\mathrm{CD} 45^{+} \mathrm{CD} 4^{+} \mathrm{CD} 8^{+}\right)$, macrófagos segundo o protocolo de marcação de Mowat \& Bain (2011) $\left(\mathrm{MHCII}^{+} / \mathrm{F} 4 / 80^{+}\right)$e macrófagos apresentadores de antígeno com possível função reguladora $\left(\mathrm{MHCII}^{+} \mathrm{F} 4 / 80^{+} \mathrm{IL}-10^{+}\right)$.

\section{Infiltrado Granulocítico}

Para caracterizar um infiltrado granulocítico, em decorrência do tratamento com DSS, utilizamos os anticorpos reveladores de granulócitos/neutrófilos, GR1 e CD11b, e avaliamos a presença destas células no tecido do cólon no $7^{\circ}$ dia do tratamento com DSS. Cinco animais tratados e três controles de cada linhagem foram utilizados neste experimento.

Observamos um aumento de células do infiltrado inflamatório $\left(\mathrm{Gr}^{+} \mathrm{CD} 11 \mathrm{~b}^{+}\right)$ com relação aos controles nos animais do grupo AIRmax, sendo que o grupo AIRmax ${ }^{S S}$ foi o que apresentou o maior aumento. Em relação aos animais do grupo AIRmin não houve diferença entre os tratados e os controles (Fig.9). Esse resultado mostra a relação entre o infiltrado inflamatório e o background genético de alta e baixa resposta, uma vez que os animais AIRmax apresentaram um maior número de células inflamatórias. 
Fig.9. Análise por citometria do infiltrado inflamatório no segmento distal.

A

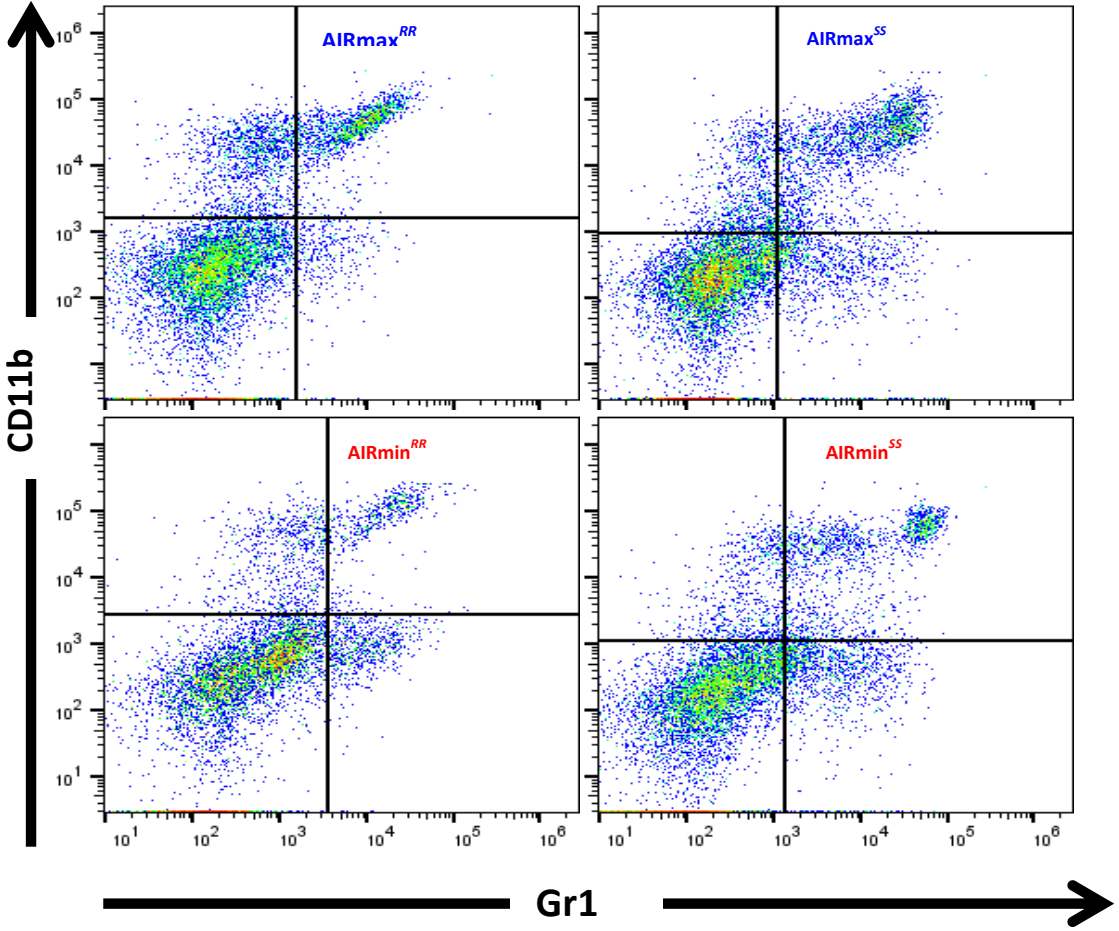

\section{$\mathrm{GR} 1^{+} \mathrm{CD} 11 \mathrm{~b}^{+}$}

B

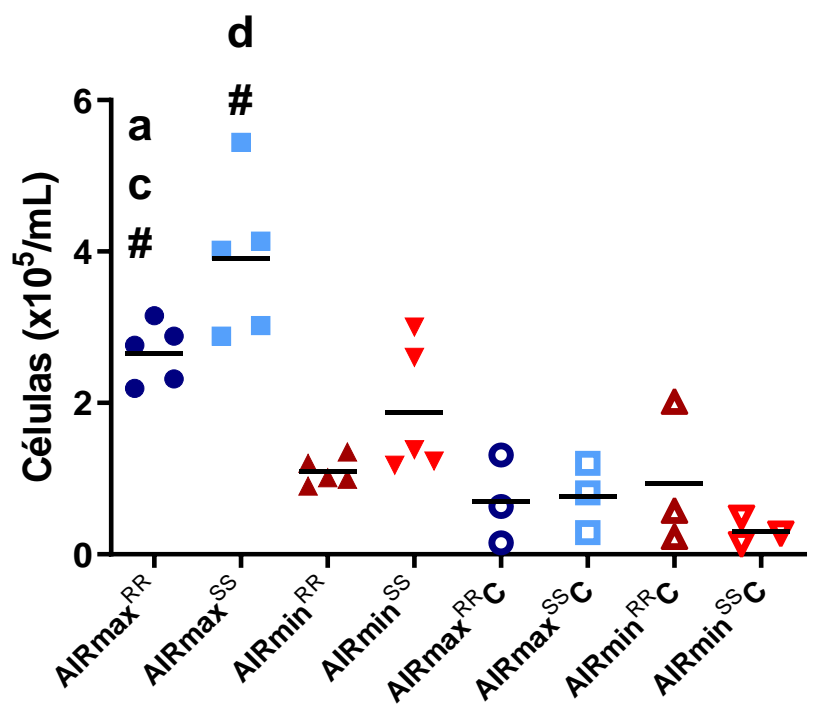

(A) Citogramas representativos da estratégia de análise das populações $\mathrm{Gr}^{+} \mathrm{CD} 11 \mathrm{~b}^{+}$dos animais $\mathrm{AIRmax}^{R R}, \mathrm{AIRmax}^{S S}, \mathrm{AIRmin}^{R R}$ e $\mathrm{AIRmin}^{S S}$ tratados com DSS 2,5\% $(n=5)$ ou que receberam apenas água $(n=3)$. (B) Número absoluto das células presentes no cólon dos animais das 4 linhagens calculado das porcentagens determinadas nas diferentes populações caracterizadas. Os resultados estão expressos com os valores individuais e média. $\mathbf{a}$ : $\operatorname{AIRmax}^{\mathrm{RR}} \mathrm{x} \operatorname{AIRmax}^{S S} \mathbf{c}: \operatorname{AIRmax}^{R R} \mathrm{x} \operatorname{AIRmin}^{R R}$; $\mathbf{d}: \operatorname{AIRmax}^{S S} \mathrm{x}$ $\mathrm{AIRmin}^{S S}$ \#: Tratado x Controle $p<0,05$ (ANOVA). 


\section{População Linfoide}

Para caracterizar as células linfoides infiltradas no tecido do cólon, estabelecemos uma estratégia de marcação com anti-CD45 para isolar as células leucocitárias $\left(\mathrm{CD} 45^{+}\right)$ do tecido e, em seguida, avaliar a presença de células CD4 e CD8 positivas nesta população (Figura 10A). As porcentagens determinadas das populações foram transformadas em número absoluto para cada linhagem e tratamento (Fig. 10B).

Utilizando a estratégia de análise apresentada na Fig. 10A, foi observado uma diferença significativa nas populações CD4 e CD8 principalmente entre os grupos $\operatorname{AIRmax}^{S S}$ e $^{A I R m i n}{ }^{S S}$ que se comportou como os controles. Com relação às outras linhagens, não foi constatada diferenças significativas, provavelmente devido à grande variação individual apresentada pelos grupos AIRmax.

Fig.10. Análise por citometria das populações celulares presentes na mucosa do cólon no segmento distal.

A
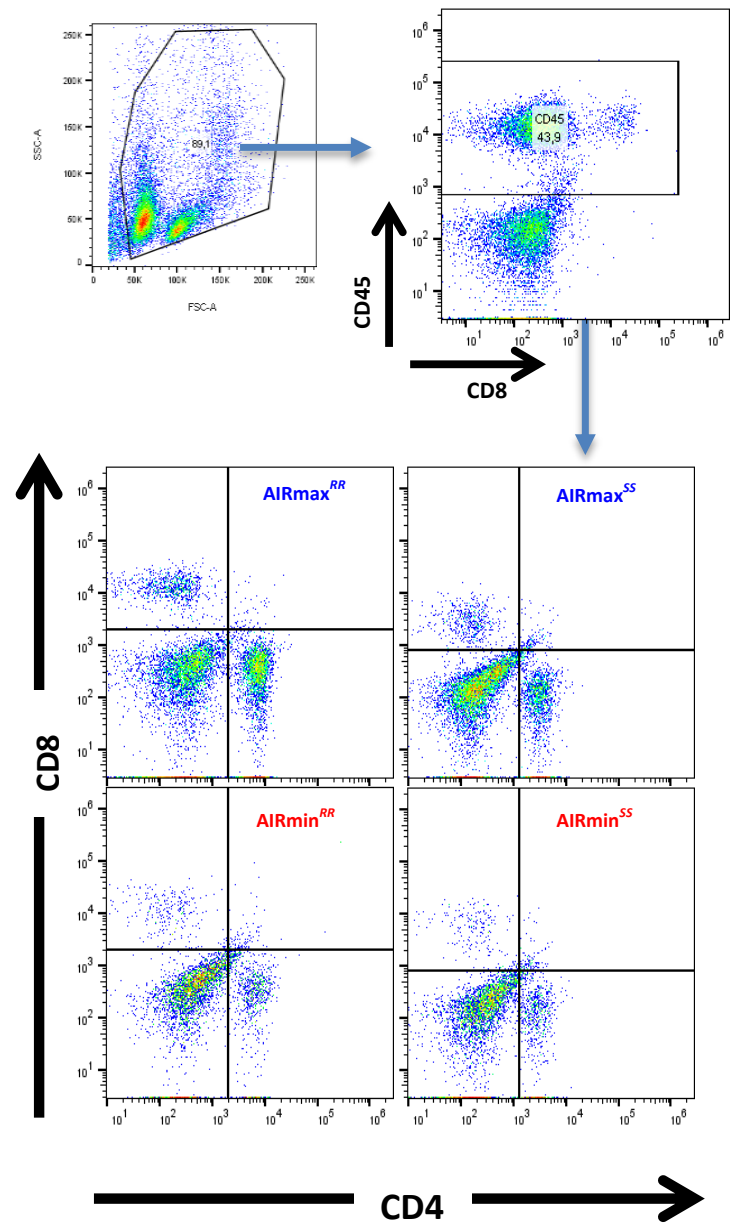
B

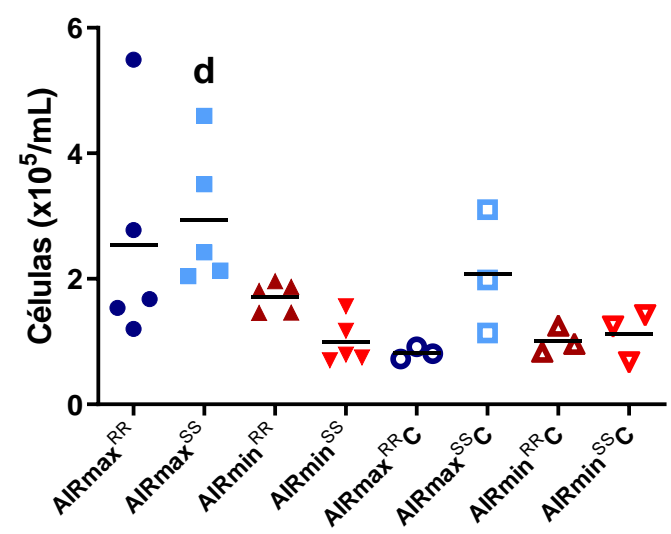

$\mathrm{CDB}^{+}$

(A) Citogramas representativos da estratégia de análise das populações $\mathrm{CD}^{+}{ }^{+}$e $\mathrm{CD} 8^{+}$dos animais $\operatorname{AIRmax}^{R R}, \operatorname{AIRmax}^{S S}, \operatorname{AIRmin}^{R R}$ e $\operatorname{AIRmin}^{S S}$ tratados com DSS 2,5\% $(n=5)$ ou que receberam apenas água $(n=3)$. (B) Número absoluto das células CD4 e (C) CD8 obtido das porcentagens destas populações presentes no cólon dos animais das 4 linhagens. Os resultados estão expressos com os valores individuais e média. d: $\operatorname{AIRmax}^{S S} \mathrm{x}$ AIRmin ${ }^{S S} p<0,05$ (ANOVA).

\section{Macrófagos}

A população de macrófagos foi caracterizada seguindo o protocolo de marcação de Mowat \& Bain (2011) que os definem como uma população duplo positiva para os marcadores F4/80 e MHC II.

Foi observado um aumento da população de macrófagos somente nos animais da linhagem AIRmax, sendo que o grupo AIRmax ${ }^{S S}$ apresentou um maior número de células aos 7 dias de tratamento. Isso indica que o fundo genético de máxima resposta inflamatória influencia no fenótipo de UC apesar da fixação dos alelos $R$ ou $S$ nestas linhagens (Fig.11). 
Fig.11. Análise por citometria das populações de macrófagos no segmento distal.

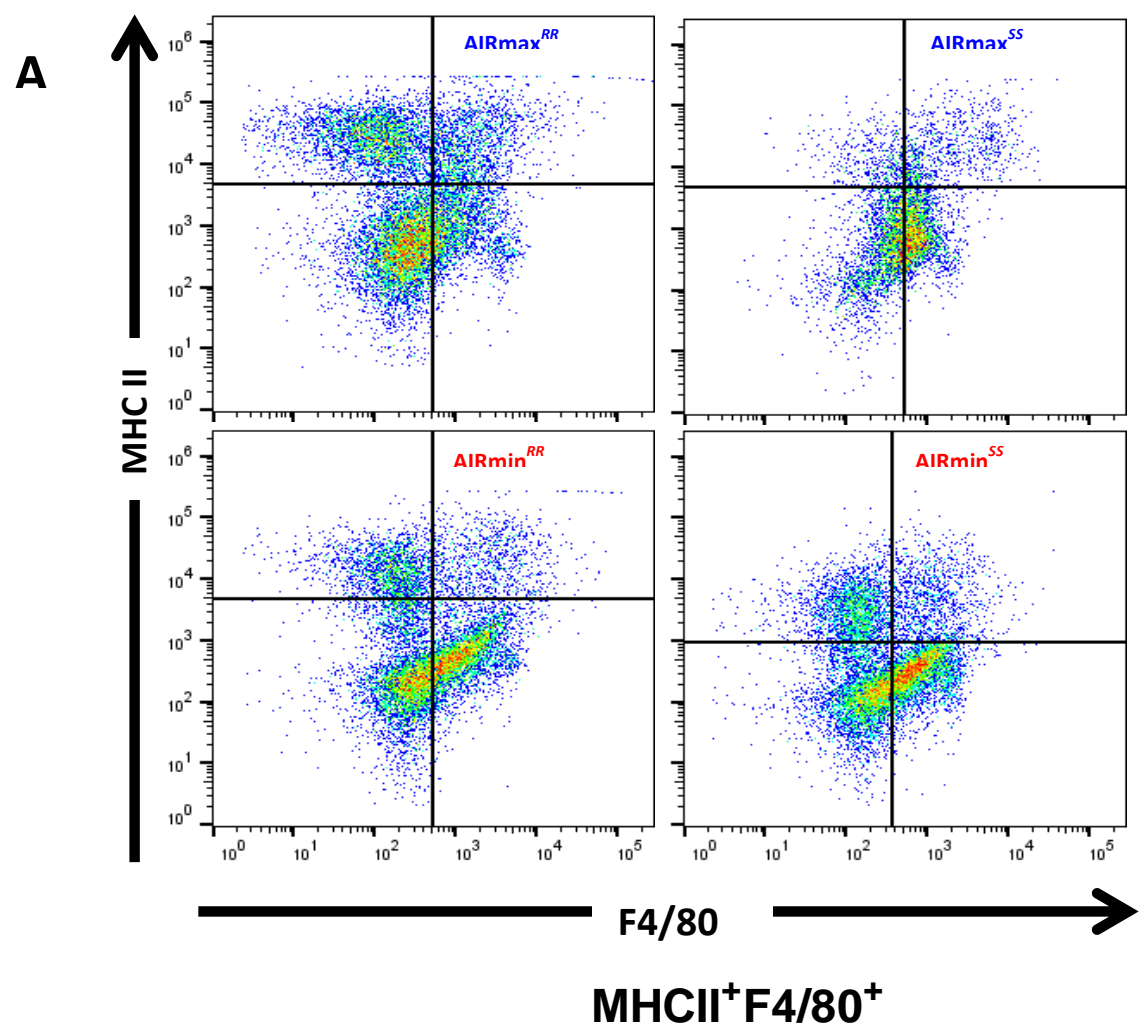

B

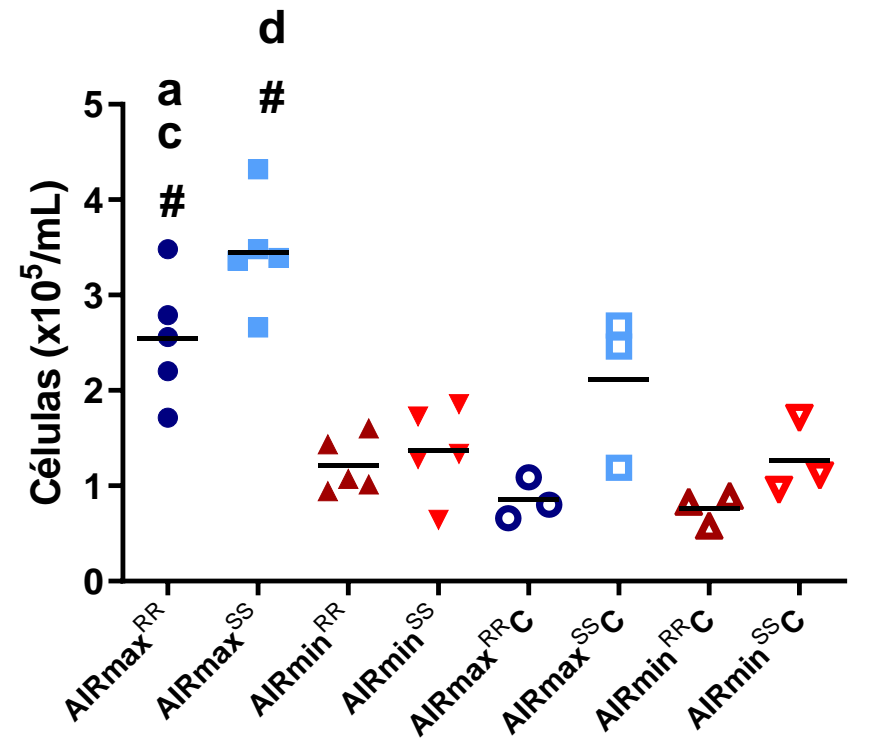

(A) Citogramas representativos das populações $\mathrm{MHCII}^{+} \mathrm{F} 4 / 80^{+}$dos animais $\mathrm{AIRmax}{ }^{R R}$, AIRmax ${ }^{S S}$, $\mathrm{AIRmin}^{R R}$ e $\mathrm{AIRmin}^{S S}$ tratados com DSS 2,5\% (n=5) ou que receberam apenas água ( $\left.n=3\right)$. (B) Número absoluto das células presentes no cólon dos animais das 4 linhagens calculado das porcentagens determinadas nas diferentes populações caracterizadas. Os resultados estão expressos com os valores individuais e média. a: $\operatorname{AIRmax}^{\mathrm{RR}} \mathrm{x} \mathrm{AIRmax}^{S S} \mathbf{c}: \operatorname{AIRmax}^{R R} \times \operatorname{AIRmin}^{R R}$; d: $\operatorname{AIRmax}^{S S} \mathrm{x} \operatorname{AIRmin}^{S S}$ \#: Tratado $\mathrm{x}$ Controle $p<0,05$ (ANOVA). 


\section{Macrófagos com função reguladora}

Dentro do grupo dos macrófagos foram analisados aqueles que teriam uma possível função reguladora ((MHC $\left.\left.\mathrm{II}^{+}\right) \mathrm{F} 4 / 80^{+} \mathrm{IL}-10^{+}\right)$(Fig.12A) e se gene Sclllal poderia exercer alguma influência nessa função.

A população considerada foi composta por células $\mathrm{MHCII}^{+} \mathrm{F} 4 / 80^{+} \mathrm{IL} 10^{+}$. Observamos que os animais do grupo $\operatorname{AIRmin}^{S S}$ foram os únicos que não apresentaram um aumento dessas células mantendo um nível basal (Fig. 12B). O que pode significar que o alelo $S$ exerce influência sobre essa população de macrófagos.

Fig.12. Análise por citometria das populações de macrófagos com função reguladora no segmento distal.

A
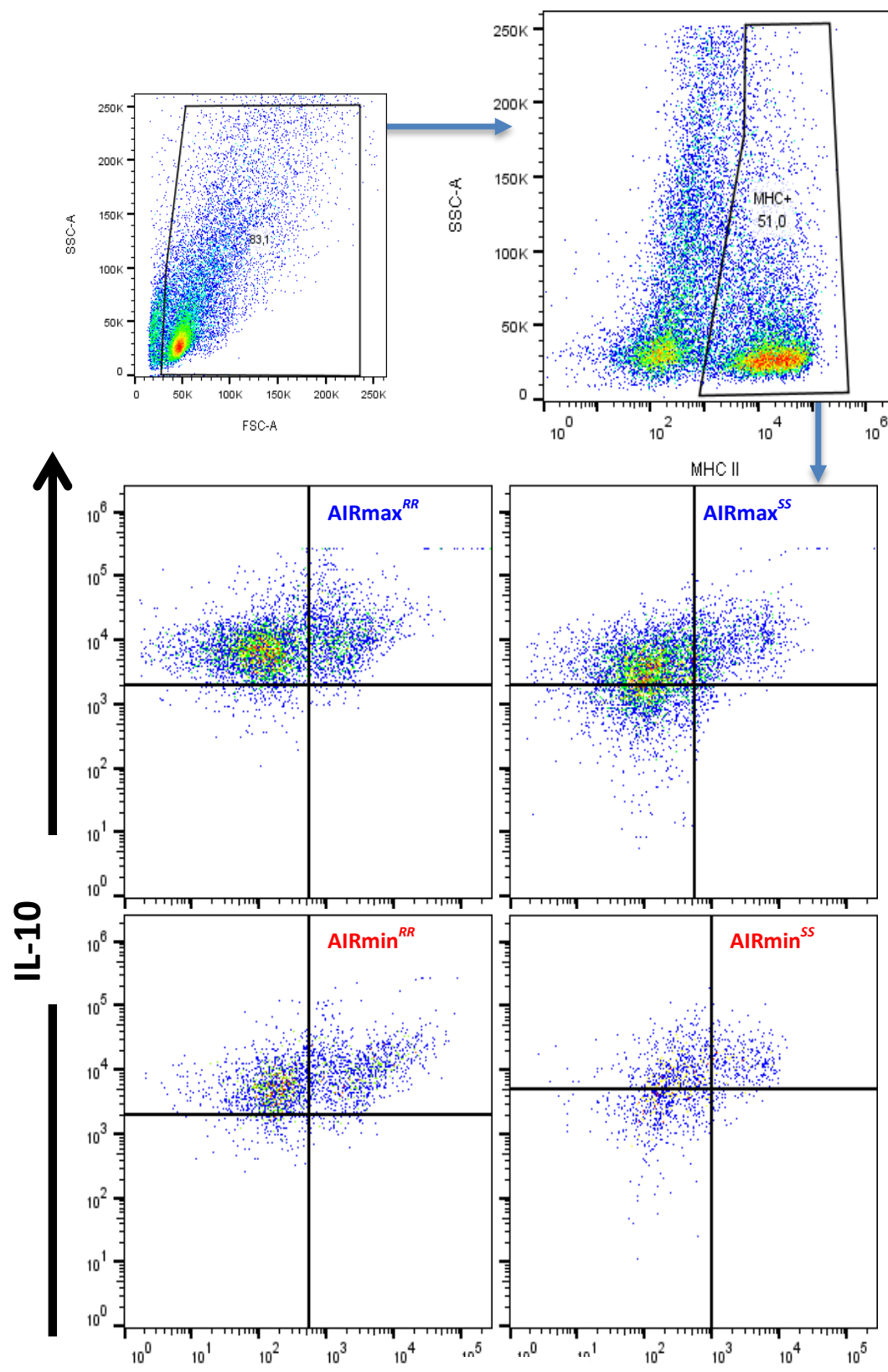


\section{$\left(\mathrm{MHCll}^{+}\right) \mathrm{F} 480^{+} \mathrm{IL}^{+} 0^{+}$}

\section{B}

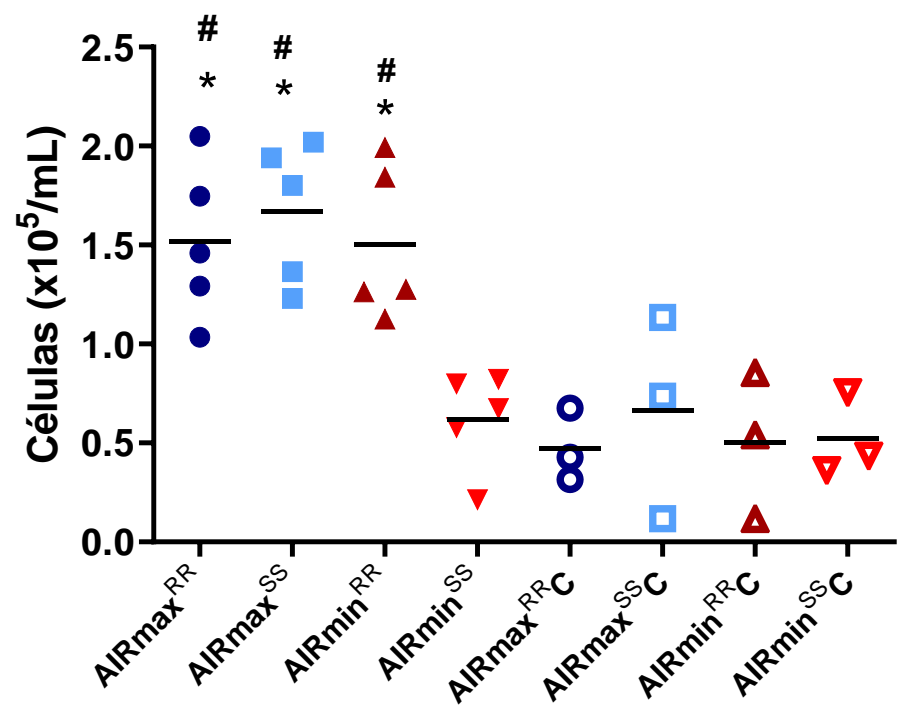

(A) Citograma representativos das populações $\mathrm{IL}-10^{+} \mathrm{F} 4 / 80^{+}$a partir da população $\mathrm{MHC} \mathrm{II}^{+}$dos animais

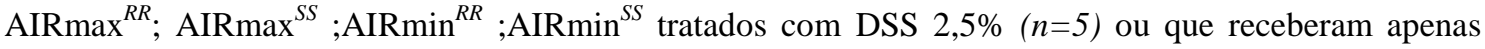
água ( $n=3$ ). (B) Animais dos grupos $\operatorname{AIRmax}^{R R}, \operatorname{AIRmax}^{S S}, \operatorname{AIRmin}^{R R}$ e AIRmin ${ }^{S S}$ tratados com DSS na concentração de $2,5 \%(n=5)$ e animais controle que receberam água $(n=5)$ foram analisados com relação a população de macrófagos com possível função reguladora $\left(\mathrm{MHC} \mathrm{II}^{+}\left(\mathrm{F} 4 / 80^{+} \mathrm{IL}-10^{+}\right)\right.$. Os resultados estão expressos com os valores individuais e média. * ${ }^{*}$ IIRmin ${ }^{S S} \mathrm{x}$ AIRmax ${ }^{R R}$ AIRmax ${ }^{S S}$ AIRmin ${ }^{R R}$ \#: Tratados x Controles $p<0,05$ (ANOVA). 


\section{Expressão Gênica de Citocinas}

Para avaliar a produção de mediadores químicos, citocinas e quimiocinas, pró e anti-inflamatórias, foi realizada uma análise da potencialidade do organismo de produzir tais mediadores por expressão gênica por meio de ensaios de PCR em tempo Real, bem como a presença de proteínas por ensaios de Multiplex. Nos dois ensaios foi utilizado o segmento distal do cólon excisado no $7^{\circ}$ dia do tratamento com DSS a 2,5\% ou água. Os grupos foram compostos de 5 animais de cada linhagem tratados ou não com DSS.

Foram observados diferentes perfis de expressão gênica nos grupos tratados de $\mathrm{AIRmax}^{R R}, \mathrm{AIRmin}^{R R}$ e AIRmin ${ }^{S S}$ nas citocinas pró- e anti-inflamatórias.

Na expressão de IL-1 $\beta$ é possível observar que os animais dos grupos AIRmax ${ }^{R R}$ e $\operatorname{AIRmin}^{S S}$ apresentaram um maior nível em relação aos demais grupos, $\operatorname{AIRmin}^{R R}$, AIRmax $^{S S}$ e controles

A expressão de IL-6 mostrou-se elevada apenas nos animais do grupo AIRmin ${ }^{S S}$ enquanto nos outros grupos ela permaneceu baixa (Fig. 13). Uma vez que o grupo $\mathrm{AIRmin}^{S S}$ mostrou-se mais sensível à indução de colite por DSS, apresentando sintomas clínicos e características histológicas que evidenciam a severidade da doença, é possível fazer uma correlação do aumento de expressão dessa citocina com o quadro de colite desenvolvido pelos animais.

Com relação a IL-10 os animais do grupo $\operatorname{AIRmax}^{R R}$ e $\operatorname{AIRmin}^{S S}$ também apresentaram maior expressão gênica desta citocina (Fig. 13). A maior expressão nos animais AIRmin ${ }^{S S}$ também está correlacionada com a severidade da doença, provavelmente devido à alguma supressão de mecanismos de reparo, visto que o grupo foi o que apresentou maior severidade na UC.

O grupo AIRmin ${ }^{S S}$ também apresentou uma expressão gênica significativamente superior de IL-17 com relação ao grupo AIRmax ${ }^{S S}$. É possível que essa diferença na expressão gênica entre os grupos seja devido ao background de baixa resposta inflamatória na presença do alelo $S$. Uma vez que entre os grupos $\operatorname{AIRmax}^{R R} \mathrm{e}$ $\operatorname{AIRmin}^{R R}$ não houve diferença na expressão. Já a expressão de TNF- $\alpha$ parece estar relacionada com e presença do alelo $R$ uma vez que os grupos $\operatorname{AIRmax}^{R R}$ e $\operatorname{AIRmin}^{R R}$ foram os que apresentaram sua maior expressão, no entanto, estes animais não 
apresentaram um quadro severo de colite. Com relação à citocina INF- $\gamma$, quimiocinas e fatores de crescimento não foi possível identificar diferenças significativas devido à alta variação dentro dos grupos (Fig. 14).

Fig.13. Expressão gênica das citocinas pró e anti-inflamatórias.
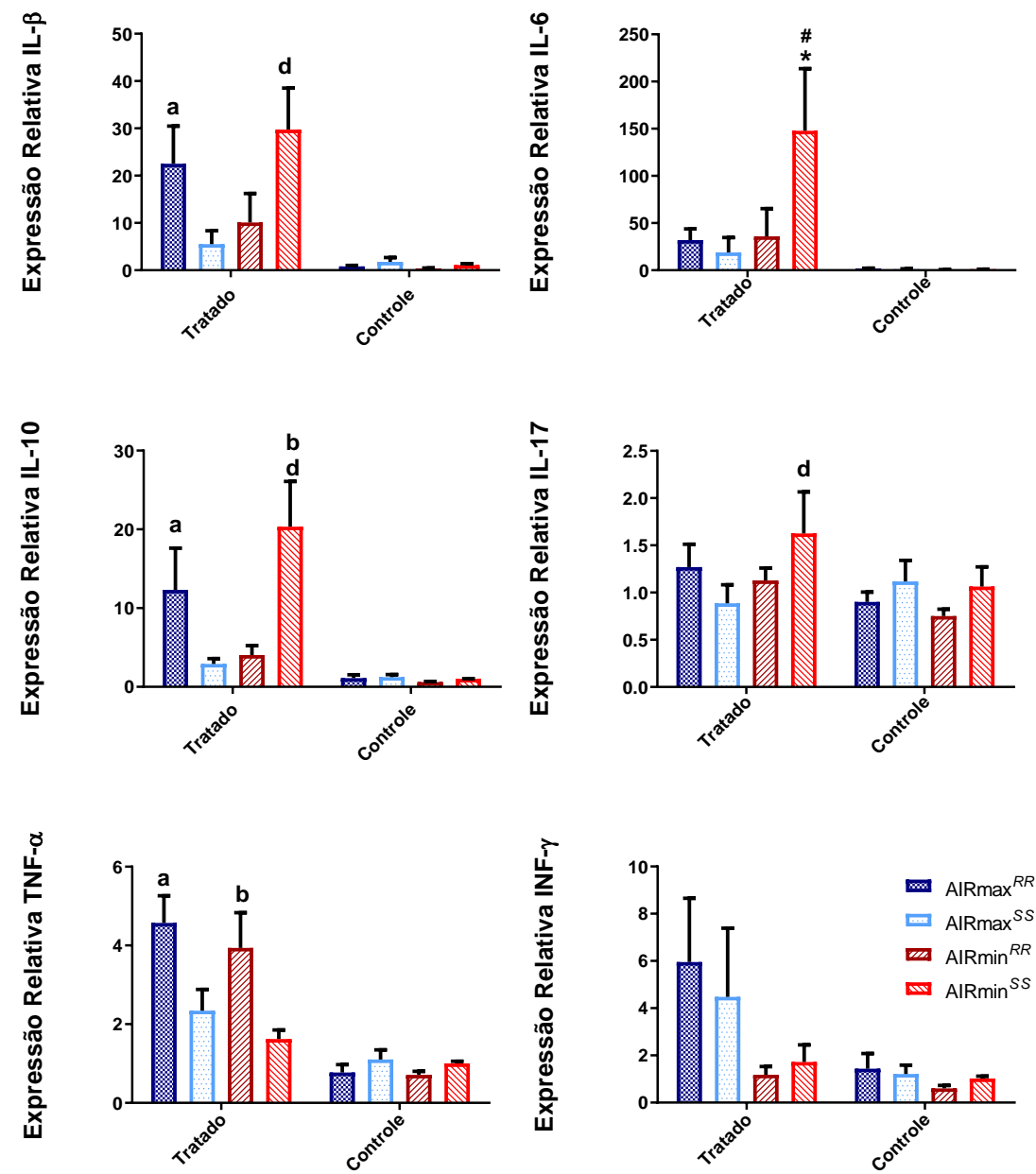

Grupos de 5 animais de cada linhagem AIRmax RR, AIRmax ${ }^{S S}$, AIRmin ${ }^{R R}$ e AIRmin ${ }^{S S}$ foram tratados com DSS $2,5 \%$ ou água durante 7 dias. Os dados estão expressos como $2^{-\Delta \Delta C t}$, expressão relativa aos respectivos calibradores $\mathrm{AIRmax}^{S S}$ e AIRmin ${ }^{S S}$ controle. Os dados estão expressos como média \pm erro padrão e as diferenças entre as médias são significativas para $p<0,05$ (ANOVA). a: $\operatorname{AIRmax}^{R R} \quad \mathrm{x}$ $\mathrm{AIRmax}^{S S}$, b: $\mathrm{AIRmin}^{R R} \mathrm{x} \mathrm{AIRmin}^{S S}$, d: $\operatorname{AIRmax}^{S S} \mathrm{x}^{\mathrm{AIRmin}}{ }^{S S} \mathbf{e}^{*} \mathrm{AIRmin}^{S S} \mathrm{x}$ AIRmax ${ }^{R R}, \mathrm{AIRmax}^{S S}$ e AIRmin. 
Fig.14. Expressão gênica de quimiocinas e fator de crescimento.
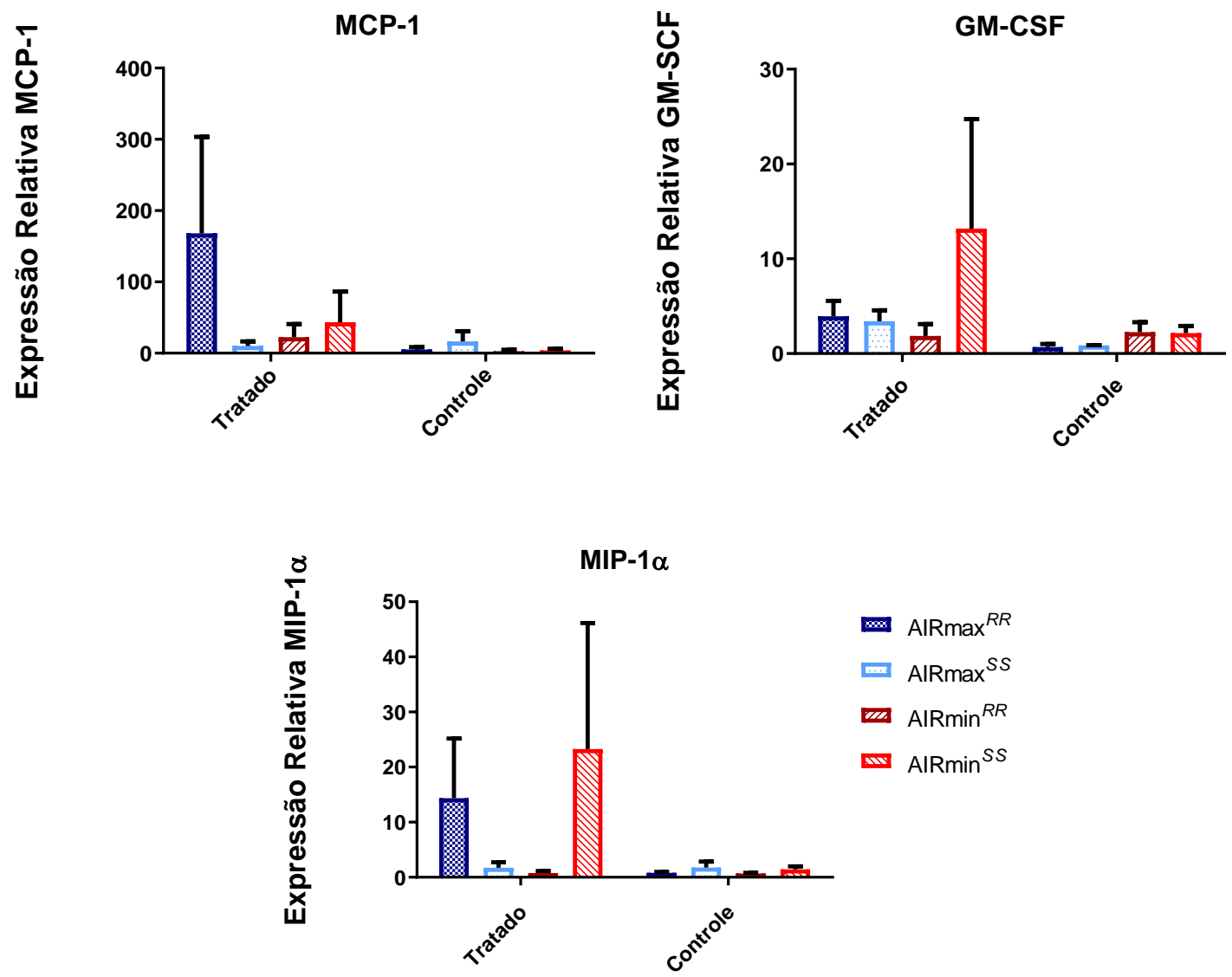

Animais dos grupos AIRmax ${ }^{R R}$ AIRmax ${ }^{S S} \operatorname{AIRmin}^{R R} \operatorname{AIRmin}^{S S}$ que foram tratados com DSS 2,5\% durante 7 dias $(n=5)$ ou água $(n=5)$ foram analisados quanto a expressão gênica de GM-CSF, MCP-1 e MIP- $1 \alpha$ no segmento distal do intestino. 


\section{Diferença na Produção de Citocinas}

Além da expressão gênica as citocinas e quimiocinas também foram analisadas no lisado de um fragmento de 50mg do segmento distal do cólon de animais tratados com DSS 2,5\% ou água. Foi utilizada a técnica de Multiplex onde foram analisadas, simultaneamente nas mesmas amostras, as citocinas IL-1, IL-6, INF $\gamma$, TNF $\alpha$, IL-17, IL4, IL-10, quimiocinas MCP-1 e MIP-1 $\alpha$ e fatores de crescimento G-CSF, GM-CSF, e M-CSF (Fig. 15).

Dentre das citocinas IL-1 $\beta$, IL-10, IL-4, IL-17, INF- $\gamma$ e TNF- $\alpha$ no grupo $\operatorname{AIRmax}^{R R}$ não foi possível observar níveis diferentes entre as quatro linhagens, ou seja, não houve qualquer alteração na produção dessas citocinas em decorrência do tratamento com DSS, apesar de algumas diferenças interlinhagens tenham sido observadas nos ensaios de PCR. Por outro lado, a concentração de IL-6 mostrou-se alta somente no grupo AIRmin ${ }^{S S}$ correlacionando em $100 \%$ com os resultados obtidos de expressão gênica desta citocina (Fig. 15).

Com relação aos fatores de crescimento avaliados, o G-CSF, assim como a IL-6, mostrou-se elevado somente no grupo AIRmin ${ }^{S S}$, enquanto os demais fatores GM-CSF e M-CSF permaneceram praticamente inalterados (Fig.16).

Este fato destaca a IL-6 e o G-CSF como sendo mediadores de grande importância no quadro da colite ulcerativa desenvolvida pelos camundongos $\operatorname{AIRmin}^{S S}$, além de uma possível interação gênica entre o alelo $S$ do gene $S c l 11 a l$ e o fundo genético de baixa resposta inflamatória aguda produzido pelo processo de Seleção Genética Bidirecional. 
Fig.15. Concentração de citocinas pró e anti-inflamatórias no cólon.

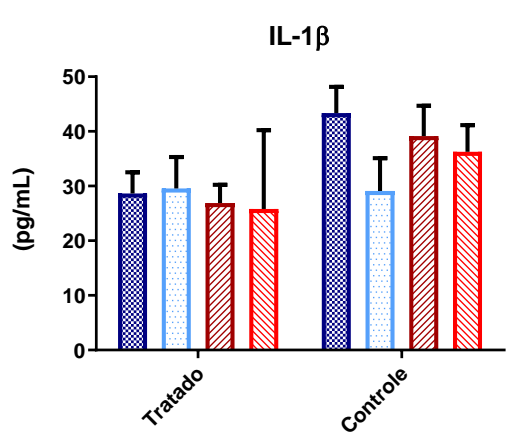

IL-10

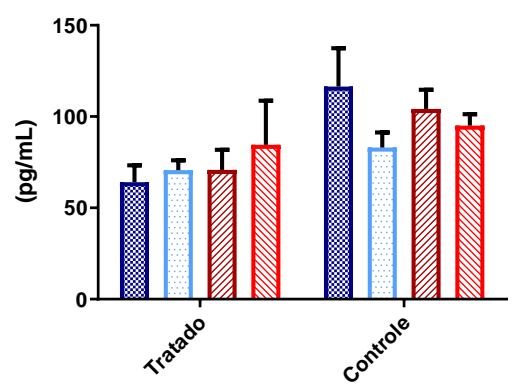

IL-4

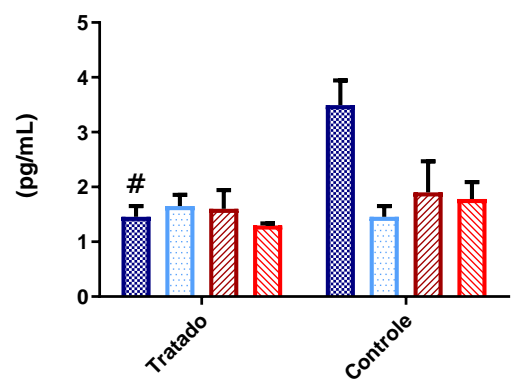

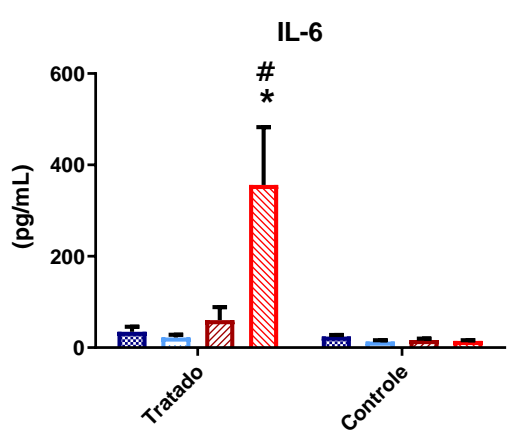

IL-17

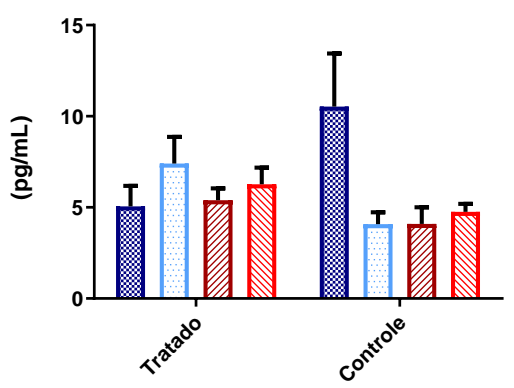

INF- $\gamma$

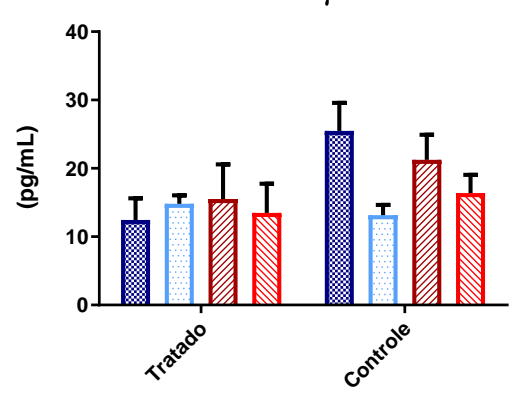

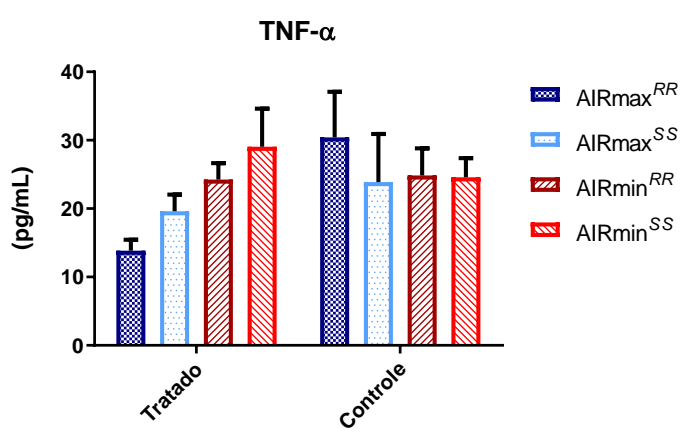

Animais dos grupos AIRmax ${ }^{R R}$ AIRmax $^{S S}$ AIRmin $^{R R}$ AIRmin ${ }^{S S}$ tratados com DSS 2,5\% durante 7 dias $(n=5)$ ou água $(n=5)$ foram analisados quanto aos níveis das citocinas no lisado do cólon. Os dados estão expressos como média \pm erro padrão e as diferenças entre as médias são significativas para $p<0,05$ (ANOVA). *AIRmin ${ }^{S S} \mathrm{x}$ AIRmax ${ }^{R R}$, AIRmax ${ }^{S S}$ e AIRmin $\mathrm{e}^{\#}$ Tratado x Controle. 
Fig.16. Concentração dos fatores de crescimento no cólon.
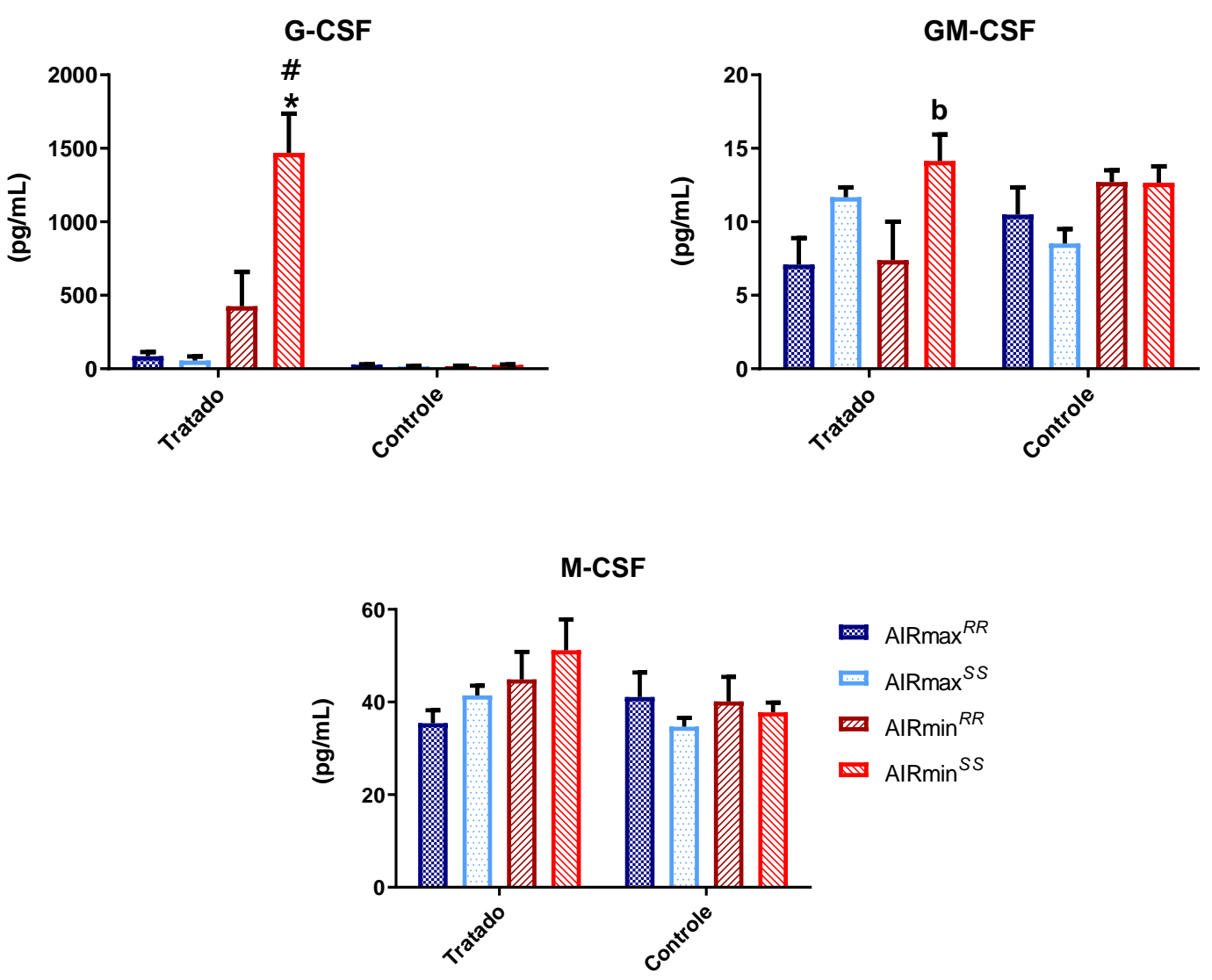

Animais dos grupos AIRmax ${ }^{R R}$, AIRmax ${ }^{S S}, \operatorname{AIRmin}^{R R}$ e AIRmin ${ }^{S S}$ tratados com DSS 2,5\% durante 7 dias $(n=5)$ ou água $(n=5)$ foram analisados quanto aos níveis de G-CSF, GM-CSF e M-CSF no segmento distal do intestino obtido no $7^{\circ}$ dia de tratamento. Os dados estão expressos como média \pm erro padrão e as diferenças entre as médias são significativas para $p<0,05$ (ANOVA). b Indica diferença entre $\mathrm{AIRmin}^{\mathrm{SS}} \mathrm{x} \mathrm{AIRmin}^{R R}$, * Indica diferença significativa de AIRmin ${ }^{S S} \mathrm{x}$ AIRmax ${ }^{R R}$, AIRmax ${ }^{S S} \mathrm{e}$ AIRmin. \# Indica diferença entre Tratado x Controle valor $p<0,05$ (ANOVA) 
Fig.17. Concentração das quimiocinas no cólon.

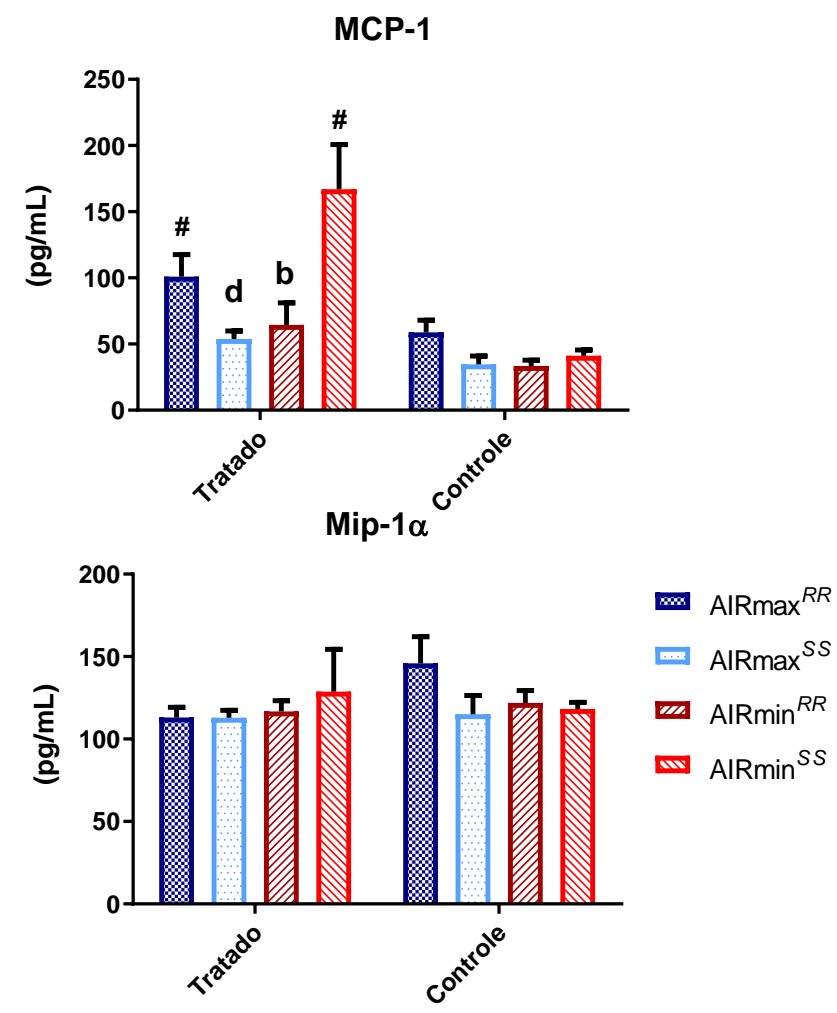

Animais dos grupos AIRmax ${ }^{R R}$ AIRmax ${ }^{S S}$ AIRmin $^{R R}$ AIRmin ${ }^{S S}$ tratados com DSS Sigma 2,5\% (n=5) durante 7 dias e animais controle que receberam apenas água $(n=5)$ foram avaliados com relação a produção de MCP-1 e MIP-1 $\alpha$. Os dados estão expressos como média \pm erro padrão e as diferenças entre as médias são significativas para $p<0,05$ (ANOVA) b: $\operatorname{AIRmin}^{S S} \times \operatorname{AIRmin}^{R R} \mathbf{d}$ : $\operatorname{AIRmax}^{S S} \times \operatorname{AIRmin}^{S S}$; \#: Tratado x Controle.

Apresentamos na Tabela 4 um resumo de todos os resultados obtidos neste trabalho, indicando as respectivas medidas em cada linhagem e, no caso de mediadores, o tipo daqueles diferencialmente expressos na linhagem AIRmin ${ }^{S S}$. Com isso, podemos destacar os seguintes parâmetros nos camundongos AIRmin ${ }^{S S}$ : IAD, taxa de sobrevida, comprimento do cólon, MPO, características histológicas (erosão e necrose), dinâmica celular (macrófagos produtores de IL10), citocinas (IL6), quimiocinas (MCP-1) e fator de crescimento (G-CSF). 
Tabela 4. Resumo dos resultados, com destaque $(*)$ para os parâmetros mais diferenciados a favor dos animais AIRmin ${ }^{S S}$.

\begin{tabular}{|c|c|c|c|c|c|}
\hline & & $\operatorname{AlRmax}^{R R}$ & $\operatorname{AlRmax}^{S S}$ & $\mathrm{AlRmin}^{R R}$ & $\operatorname{AIRmin}^{S S}$ \\
\hline & IAD (escore) & 2 & 1,5 & 2 & $9.2^{*}$ \\
\hline & Sobrevida (\%) & 100 & 100 & 100 & $75^{*}$ \\
\hline & Cólon (cm) & 10 & 10 & 10 & $7^{*}$ \\
\hline & MPO (DO) & 400 & 150 & 250 & $100^{*}$ \\
\hline & Inflamação & 5 & 2 & 2 & 3 \\
\hline$\underset{\sim}{\dddot{\sim}}$ & Erosão & 0,5 & 0,5 & 0,5 & $3^{*}$ \\
\hline O & Tec.granulação & 2 & 1,5 & 2 & 3 \\
\hline 㟔 & Necrose & 2 & 0,5 & 2 & $3^{*}$ \\
\hline & Edema & 2,5 & 1,5 & 1,5 & 1,5 \\
\hline & Total & 25 & 30 & 20 & 15 \\
\hline & Granulócito & 2,5 & 4 & 1 & 2 \\
\hline$\underline{\xi}$ & CD4 & 2,5 & 3 & 2 & 1 \\
\hline 10 & CD8 & 1 & 1,2 & 0,7 & 0,5 \\
\hline $\bar{x}$ & Macrófagos & 2,5 & 3,5 & 1,5 & $1,5^{*}$ \\
\hline & Macrófago/IL10 & 1,5 & 1,7 & 1,5 & $0,7^{*}$ \\
\hline & $\begin{array}{l}\text { Expressão } \\
\text { Gênica }\end{array}$ & & & & \\
\hline & Citocinas & IL1 $\beta / I L 10 / T N F \alpha$ & TNFa/IFNy & TNFa & IL1 $\beta$ /IL6/IL10 \\
\hline & Quimiocinas & - & - & - & - \\
\hline & $\begin{array}{l}\text { Fator de } \\
\text { Crescimento }\end{array}$ & - & - & - & - \\
\hline & Multiplex & & & & \\
\hline & Citocinas & - & - & - & IL6 $^{*}$ \\
\hline & Quimiocinas & MCP-1 & - & - & MCP-1 \\
\hline & $\begin{array}{l}\text { Fator de } \\
\text { crescimento }\end{array}$ & - & - & - & G-CSF ${ }^{*}$ \\
\hline
\end{tabular}

* Parâmetros com diferença a favor do grupo dos animais AIRmin ${ }^{\text {SS }}$ 
A colite ulcerativa é uma doença cuja etiologia ainda não foi completamente elucidada sendo que vários fatores, ambientais e genéticos, podem levar ao desenvolvimento da doença (Tatiya-Aphiradee; Chatuphonprasert; Jarukamjorn, 2018). Por se tratar de uma doença complexa multifatorial, a regulação genética é regulada por diferentes genes ou loci gênicos. Muitos candidatos foram descritos para regular essa doença, no entanto alguns deles foram muito pouco explorados experimentalmente.

O presente estudo objetivou avaliar a participação do gene Sclllal no desenvolvimento da Colite Ulcerativa. O gene Slc1lal codifica uma proteína que é uma transportadora de íons $\mathrm{Fe}^{+}$e $\mathrm{Mn}^{+}$presente em populações leucocitárias, especialmente macrófagos e monócitos, e é importante no combate a infecções bacterianas. Jiang et al (2009) foi o primeiro e único a demonstrar experimentalmente uma associação desse gene com a colite ulcerativa induzida por DSS em camundongos mutantes de fundo genético C57B10. A presença de uma mutação, que causa a perda de função da proteína, segundo o autor, melhora o quadro de colite, quando avaliados os parâmetros de perda de peso e redução do comprimento do cólon (Jiang et al, 2009).

Em 2006, pesquisadores do Laboratório de Imunogenética do Instituto Butantan apresentaram um estudo da expressão fenotípica da Colite Ulcerativa induzida por DSS em camundongos geneticamente heterogêneos produzidos por Seleção Genética Bidirecional, considerando a resposta inflamatória aguda a corpo estranho, AIRmax e AIRmin (Di Pace et al, 2006).

Estas duas linhagens foram utilizadas por apresentarem uma maior complexidade genética em relação às linhagens isogênicas comumente usadas para o estudo da regulação genética da UC. Neste estudo, foram avaliados alguns parâmetros relacionados à UC como perda de peso, consistência das fezes e sangramento, compondo o Índice de Atividade da Doença (IAD), conforme proposto por Stevceva e colaboradores em (1999). Além disso foram avaliadas as expressões gênicas de algumas citocinas pró- e anti-inflamatórias e alguns aspectos histopatológicos. Nesse estudo, os animais AIRmax apresentaram maior severidade da UC do que os AIRmin quando induzida com 2,5\% de DSS. Considerando os componentes inflamatórios da UC, estes resultados acompanharam os respectivos fenótipos de AIR, ou seja, animais selecionados para a alta capacidade inflamatória aguda desenvolve UC mais intensa (Di Pace et al., 2006).

Como estas linhagens apresentam polimorfismo no gene Slc11al, foi realizado um processo seletivo por genotipagem para os alelos $R$ e $S$ do referido gene. Assim 
foram produzidas as quatro sublinhagens AIRmax e AIRmin homozigotas para os alelos $R$ (resistência) e $S$ (suscetibilidade) do gene (Araujo et al., 1998; Borrego et al., 2006).

No sentido de ampliar o entendimento da participação do gene Slcllal na regulação genética da UC, utilizamos essas sublinhagens por apresentarem um fundo genético heterogêneo, o que torna um modelo mais adequado para a extrapolação em populações naturais como a população humana.

Utilizando as mesmas condições de indução de UC, com uma pequena modificação nos escores do IAD, obtivemos resultados de maior amplitude àqueles preconizados no estudo de Jiang (Jiang et al, 2009), ou seja, a proteína SLC11A1 defectiva não só apresenta uma ação protetora, como também permissiva ao desenvolvimento da doença. Estes fenótipos opostos dependem ou estão relacionados com o background genético de máxima ou de mínima AIR, ou seja, animais AIRmin ${ }^{\text {ss }}$ foram sensíveis, enquanto os AIRmax ${ }^{\text {ss }}$ foram resistentes.

O grupo representado pelos animais AIRmin ${ }^{S S}$ mostrou maior sensibilidade ao DSS, apresentando um aumento significativo no IAD a partir do $6^{\circ}$ dia de tratamento, atingindo um escore máximo de 9,2 caracterizado por diarreia, sangramento, perda de peso acentuada e uma diminuição do comprimento do cólon. Esse resultado demonstra claramente uma relação entre o gene Scl11al defectivo e o desenvolvimento da colite. Por outro lado, os animais com o gene defectivo, mas com genética de alta capacidade inflamatória não desenvolveu a doença de maneira importante.

A partir do fenótipo IAD, estabelecido nas sublinhagens AIRmax e AIRmin homozigotas para os alelos $R$ ou $S$, foram realizadas análises histológicas a fim de verificar os danos causados pelo tratamento, correlacionando-as com os sintomas clínicos apresentados.

Foi observado um infiltrado inflamatório presente em todos os grupos, no entanto, eles apresentaram diferenças com relação ao efeito causado na mucosa pelo DSS. Foram utilizadas duas categorias para avaliar os danos causados pelo tratamento 1. Danos na Arquitetura Tecidual representado pelos parâmetros: Erosão, Tecido de granulação e Edema de Submucosa; e 2. Modificações Epiteliais cujo os parâmetros apresentados foram: Hiperplasia e Necrose.

Para a linhagem AIRmax, os animais $\operatorname{AIRmax}^{R R}$ apresentaram vários danos a arquitetura tecidual caracterizados por uma grande quantidade de tecido de granulação, edemas na submucosa e também alterações epiteliais identificadas por uma alta necrose/perda glandular. Já o grupo $\operatorname{AIRmax}^{S S}$ foi o que sofreu menos danos, 
evidenciados por tecido de granulação e edemas na submucosa, mas mantendo a arquitetura do cólon.

Nos grupos AIRmin, os animais AIRmin $^{R R}$ também mostraram danos na arquitetura tecidual devido a presença de tecido de granulação e edemas na submucosa, além de alterações epiteliais evidenciadas através de hiperplasia e necrose ou perda glandular. Os animais AIRmin ${ }^{S S}$ apresentaram lesões mais graves, correlacionando-se com a severidade da doença (IAD), caracterizadas por danos na arquitetura tecidual devido a uma intensa erosão, tecido de granulação e alterações epiteliais com um alto índice de necrose/perda glandular. De fato, estas observações são comumente encontradas em modelos experimentais em que o DSS leva a um quadro de inflamação em decorrência de danos da barreira epitelial, desregulação da expressão das moléculas de adesão, com consequente disfunção da permeabilidade intestinal (Eichele, \& Kharbanda, K, 2017).

Baseando-se nos dados de histopatologia, é possível inferir que os animais AIRmin ( $R R$ ou $S S)$ são mais sensíveis aos efeitos do DSS, visto que sofreram grandes alterações epiteliais. Apesar dos animais do grupo AIRmax também apresentarem danos, estes parecem ter sido causados pela intensa inflamação e não unicamente pela sensibilidade ao DSS. Portanto os sintomas clínicos severos observados nos animais AIRmin $^{S S}$ podem ser devido à sensibilidade desse grupo aos efeitos diretos do DSS o que levou a uma perda quase que completa da sua barreira epitelial e destruição da arquitetura da mucosa. Este quadro tem sido descrito para diferentes modelos experimentais de UC induzida por DSS, como por exemplo os animais das linhagens isogênicos, BALB/c, C57B1/6 e C3H/He/J, conforme revisado por Derrick Eichele em 2017.

Uma vez observado a presença de um infiltrado celular caracterizado como sendo inflamatório em todos os grupos, avaliamos as populações celulares presentes nesse infiltrado a fim de verificar possíveis associações com a gravidade da doença. Para isso foram analisadas as diferentes populações: Granulócitos $\left(\mathrm{Gr} 1^{+} / \mathrm{CD} 11 \mathrm{~b}^{+}\right)$, Linfócitos $\left(\mathrm{CD}^{4} 5^{+} \mathrm{CD} 4^{+}\right)$ou $\left(\mathrm{CD} 45^{+} \mathrm{CD} 8^{+}\right)$, Macrófagos $\left(\mathrm{F} 4 / 80^{+} \mathrm{MHCII}^{+}\right)$e Macrófagos produtores de IL-10 (MHC $\left.\mathrm{II}^{+} \mathrm{F} 4 / 80^{+} \mathrm{IL}^{-10^{+}}\right)$.

A primeira diferença observada foi em relação ao infiltrado granulocítico caracterizado por células $\mathrm{Gr} 1^{+} \mathrm{CD} 11 \mathrm{~b}^{+}$. Os animais do grupo AIRmax apresentaram um maior número de células com relação aos animais AIRmin, sendo que o grupo $\operatorname{AIRmax}^{S S}$ foi o que apresentou maior concentração de células. De fato, estas linhagens 
têm capacidade de produzir reação inflamatória mais intensa do que os AIRmin devido à seleção de genes reguladores da alta AIR (Borrego et al., 2006).

A partir desses resultados foi realizada uma medida indireta da atividade de neutrófilos através do ensaio de MPO para avaliar a participação dessas células no fenótipo da colite por DSS. A MPO mostrou-se aumentada apenas nos grupos $\operatorname{AIRmax}^{R R}$ e AIRmin ${ }^{R R}$, sendo possível uma associação entre a atividade desta enzima e o alelo $R$ independentemente do background genético. $\mathrm{O}$ aumento da atividade da MPO é um marco em modelos de colite por DSS especialmente na fase aguda, sendo os neutrófilos uma das populações responsáveis pela inflamação (Bento et al, 2012; Randhawa, et al, 2014). No entanto, essa atividade não parece estar relacionada com o fenótipo da colite uma vez que os animais $\operatorname{AIRmin}^{S S}$ não apresentaram um aumento da atividade dos neutrófilos.

A disfunção na barreira epitelial e, portanto, um aumento de permeabilidade, provocados pelo DSS, pode levar a uma ativação do sistema imune pela própria microbiota (Eichele \& Kharbanda, 2017; Munyaka et al. 2016). A constatação de um maior infiltrado granulocítico em animais AIRmax (RR ou SS) com relação aos AIRmin, nos leva a inferir que esta diferença é devido à seleção AIR, ou seja, animais selecionados para alta resposta inflamatória possuem maior atividade da medula óssea com consequente elevada produção de células (Ribeiro et al., 2003), embora ocorra uma alta produção de G-CSF pelas células do epitélio intestinal na linhagem AIRmin ${ }^{S S}$.

Já o maior número de células observadas no grupo AIRmax ${ }^{S S}$, em relação aos animais AIRmax ${ }^{R R}$ pode estar relacionado ao Slcllal ou genes associados determinando maior ou menor infiltrado celular em resposta ao DSS. Esta diferença de infiltrado celular entre as linhagens AIRmax foi também observada para a AIR induzida por Biogel (Borrego et al., 2006).

A população linfoide também foi avaliada, caracterizando-se a partir de uma população $\mathrm{CD} 45^{+}$linfócitos $\mathrm{CD}^{+}$ou $\mathrm{CD}^{+}$. Houve uma diferença estatisticamente significante entre o grupo AIRmax ${ }^{S S}$ em relação aos AIRmin ${ }^{S S}$. No entanto, como não houve uma diferença significativa em relação aos respectivos controles é possível que essa seja uma variação natural das linhagens, não contribuindo para o fenótipo da colite. De acordo com a literatura na fase, de 7 dias de DSS, o infiltrado celular é predominantemente neutrofílico e macrofágico (Bento et al, 2012).

Com relação aos macrófagos, duas abordagens de marcação foram utilizadas, seguindo o protocolo de Mowat \& Bain (2011): uma população F4/80 ${ }^{+} \mathrm{MHCII}^{+}$ 
caracterizada como macrófagos e outra de células apresentadoras de antígeno produtoras de $\mathrm{IL}-10\left(\mathrm{MHC} \mathrm{II}^{+} \mathrm{F} 4 / 80^{+} \mathrm{IL}-10^{+}\right.$), consideradas como macrófagos que possuem uma atividade reguladora.

Nos macrófagos $\mathrm{F}_{4} / 80^{+} \mathrm{MHCII}^{+}$, foi observado um padrão semelhante aos granulócitos onde houve aumento da população apenas nos animas AIRmax, sendo que o grupo AIRmax ${ }^{S S}$ apresentaram um maior número de células. Como relatado anteriormente, a UC por DSS na fase aguda acontece pela ação principal de macrófagos e neutrófilos (Bento et al, 2012), sendo que os macrófagos contribuem através da produção de radicais de oxigênio (ROS), mediadores químicos como citocinas e quimiocinas e podem afetar a integridade do epitélio, contribuindo para um aumento da permeabilidade em casos de inflamação (Lissner et al, 2015). Esses macrófagos, por seguirem o mesmo padrão do perfil dos granulócitos, isto é, AIRmax maior do que AIRmin, significa que o background de alta resposta inflamatória está relacionado com esta diferença.

A população de macrófagos do cólon deriva de uma população de monócitos que ao entrar na mucosa sofrem uma diferenciação in situ com a aquisição gradual de MHCII, F4 / 80, CD64, CD11c, CX3CR1 e perda de Ly6C. Essa população é chamada de residente e tem como característica a produção de citocinas anti-inflamatórias como IL-10 e TGF- $\beta$ (BAIN et al, 2014). Esta população de células pode ser importante na supressão da colite experimental por DSS juntamente com células dendríticas residentes da mucosa (Qualls et al, 2006). Assim, as células de fenótipo MHC $\mathrm{II}^{+} \mathrm{F} 4 / 80^{+} \mathrm{IL}-10^{+}$ encontradas no epitélio do cólon sob a ação do DSS podem ter a função reguladora da UC, uma vez que estavam presentes em todos os grupos exceto nos AIRmin ${ }^{S S}$. Uma vez que os efeitos pleiotrópicos do gene Slcllal afetam a atividade dos macrófagos (Barton; Whitehead; Blackwell, 1995), isto poderia levar à diminuição do número dessas células, contribuindo para o aumento da inflamação e consequente cronificação da doença nos AIRmin ${ }^{S S}$.

Uma vez que a colite por DSS é caracterizada pela produção de vários mediadores químicos como citocinas, quimiocinas e fatores de crescimento, foi feita uma avaliação com relação à produção desses mediadores por meio de expressão gênica e a presença de proteínas.

O aumento dos níveis de IL-1 $\beta$ está relacionado com a resposta inflamatória na colite por DSS (Eichele \& Kharbanda, 2017). Na análise da expressão gênica, houve um aumento de IL-1 $\beta$ nos grupos $\operatorname{AIRmax}^{R R}$ e AIRmin $^{S S}$ enquanto que os níveis desta 
citocina no lisado do cólon não apresentaram diferença. É descrito na literatura que a expressão gênica de IL-1 $\beta$ está aumentada na fase aguda e os níveis da proteína aumenta preferencialmente na fase crônica (Bento et al, 2012; Egger et al, 2000).

A IL-6 é produzida por linfócitos T, macrófagos e células endoteliais em casos de inflamação na mucosa e é uma das citocinas que contribui para o influxo de leucócitos (Mudter; Neurath, 2007), induz a diferenciação de células B em plasmócitos (Muraguchi, Atsushi et al, 1988), aumenta a citotoxicidade dependente de anticorpo (Tsang et al 1991) e foi visto que ela está relacionada ao aumento da severidade da doença em humanos e em modelos experimentais murinos (Li et al, 2010, Bento et al, 2012; Egger et al, 2000).

Esta interleucina também está envolvida em cascatas de sinalização e imunorregulação, apor meio da ligação com seu receptor (IL-6R) em células gp130 positivas ativando o fator de transcrição STAT3 (Signal Transducer and Activator of Transcription-3), tendo sido associada a uma cronificação da doença e aumento de incidências de câncer de cólon (Bollrath, et al, 2009; Grivennikov, et al 2009; Müzes, et al, 2012; Waldner; Neurath, 2014).

No nosso caso, foi observado um aumento de IL-6 no grupo AIRmin ${ }^{S S}$ tanto na expressão gênica como na concentração da proteína, o que é um indício de sua importância no fenótipo da colite nesses animais. Já foi reportado o aumento dessa citocina em modelos de colite por DSS ainda na fase aguda da doença com permanência durante a fase crônica (Alex et al, 2009), um indicativo de uma possível cronificação da doença no grupo AIRmin ${ }^{S S}$. Jiang et al., 2009 também observou um aumento da expressão gênica de IL-6 no $7^{\circ}$ dia de tratamento, no entanto, isso ocorreu apenas nos animais que possuíam o fenótipo Scll lal ${ }^{\mathrm{wt}}$ (selvagem) portadores da proteína funcional o que contribuiu para a conclusão do autor de uma suposta proteção da colite nos animais $S c l 11 a l^{\mathrm{mt}}$ (mutado) cuja proteína é defectiva.

A IL-10 é uma citocina anti-inflamatória que também está presente na colite. Foi observado um aumento da expressão desta citocina nos grupos $\operatorname{AIRmax}^{R R}$ e $\operatorname{AIRmin}^{S S}$, no entanto não houve nenhuma diferença significativa na concentração da proteína no lisado do cólon. É descrito aumento da expressão gênica dessa citocina em modelos de DSS na fase aguda (Egger, et al, 2000) e da proteína na fase crônica da doença (Alex et $a l, 2009)$. Isso poderia explicar a expressão de IL-10 no grupo AIRmin ${ }^{S S}$, mas não da proteína no lisado, provavelmente por não ter atingido o estágio crônico. Também é 
possível que a presença do alelo $S$ possa estar interferindo na produção desta citocina, uma vez que foi visto uma diminuição das populações produtoras de IL-10 no cólon.

O TNF- $\alpha$ é uma das citocinas consideradas como marcadoras no modelo de colite por DSS (Eichele \& Kharbanda, 2017) e sua expressão bem como a concentração proteica aparecem aumentadas na fase aguda (Alex et al, 2009; Egger, et al, 2000). Houve um aumento da expressão de TNF- $\alpha$ nos grupos $\operatorname{AIRmax}^{R R}$ e $\operatorname{AIRmin}^{R R}$, mas não foi acompanhado pela concentração da proteína no sobrenadante, sugerindo que a expressão gênica pode estar relacionada com a presença do alelo $R$. É possível que, embora haja uma alta expressão, não esteja havendo a produção da proteína devido a mecanismos de regulação pós-transcricionais que podem estar relacionados com a presença do alelo $R$ bem como pelo background de alta resposta inflamatória.

A colite induzida por DSS também leva a um aumento do nível do fator de crescimento G-CSF (Ito et al, 2008). Em estudos utilizando modelo de colite por DSS com as linhagens isogênicas (C57BL/6 e BALB/c) foi visto uma associação entre a concentração de G-CSF e a cronificação da doença (Melgar; Karlsson; Michaëlsson, 2005). Nos nossos resultados, o G-CSF esteve aumentado apenas nos animais $\operatorname{AIRmin}^{S S}$, provavelmente relacionado com a destruição da barreira epitelial pelo DSS, uma vez que os animais AIRmax apresentaram níveis mínimos de G-CSF independentemente do alelo. Kamezaki et al (2005) mostrou in vitro que, além do papel na maturação e proliferação de células da linhagem neutrofílica, o G-CSF também pode prolongar o tempo de vida dessas células, prevenindo a apoptose. Portanto, mesmo que a atividade da mieloperoxidade estivesse baixa nos animais AIRmin ${ }^{S S}$ é possível que a grande concentração de G-CSF estivesse impedindo a apoptose dos neutrófilos, que por sua vez contribuíram para o processo inflamatório, severidade e possível cronificação da doença.

Com relação à quimiocina MCP-1, Khan et al (2006) demonstrou a importância dessa quimiocina no modelo experimental para colite em camundongos utilizando DNBS (Ácido Dinitrobenzenesulfônico) através da modulação da produção de citocinas e da intensidade do infiltrado inflamatório. Os animais AIRmin ${ }^{S S}$ também apresentaram um aumento na concentração, mas não na expressão gênica. Uma vez que essa quimiocina mostrou um aumento apenas na fase crônica da doença (Alex et al, 2009), isto pode ser um indicativo de contribuição para o quadro inflamatório da doença nos AIRmin $^{S S}$ e possível relação entre a presença do alelo $S$ no background inflamatório de baixa resposta com a sensibilidade a colite. 
O nosso trabalho sugere fortemente a influência do gene Slc1lal no fenótipo da UC. Indivíduos que apresentam o alelo $R$ são resistentes à UC independente do background genético da alta ou baixa capacidade inflamatória. No entanto, quando ocorre a fixação do alelo $S$ com o background genético de baixa resposta inflamatória $\left(\mathrm{AIRmin}^{S S}\right)$, o fenótipo de resistência à colite apresentado pela linhagem AIRmin parental é alterado.

Por fim, consideramos que o uso de animais com características genéticas selecionadas e o fundo genético heterogêneo preservado constituem modelo adequado e alternativo àqueles com linhagens isogênicas mutantes, para o estudo translacional de fenômenos complexos e multifatoriais como é a Colite Ulcerativa. 
Os dados experimentais obtidos por meio da mensuração de parâmetros clássicos de UC induzida por DSS como alto índice de atividade da doença (IAD), maior porcentagem de perda de peso corpóreo, menor taxa de sobrevida e diminuição do tamanho do cólon são claros e reforçam a candidatura do alelo $S l c 11 a 1^{S S}$, presente em fundo genético de mínima resposta inflamatória (AIRmin), na sensibilidade à Colite Ulcerativa.

A destruição epitelial provocada pelo DSS, constatada pelas análises histopatológicas, ocorreu sobretudo nos animais que apresentaram o alelo $S$, com background genético de mínima resposta inflamatória aguda, corroborando os aspectos clínicos (IAD).

$\mathrm{Na}$ avaliação das populações celulares presentes no epitélio do cólon aos 7 dias do tratamento com DSS, verificamos inicialmente que os fenótipos de alta ou baixa reatividade inflamatória foram preservados nas linhagens AIRmax ou AIRmin, respectivamente, independente do alelo $R$ ou $S$.

As abordagens de expressão gênica e de proteínas revelaram altas concentrações de IL6, G-CSF e MCP-1. Estes fatores estão associados com o fenótipo de alta intensidade da doença nos AIRmin ${ }^{S S}$. Portanto, este resultado aparentemente contraditório pode ser um mecanismo compensatório dado o baixo nível inflamatório desta linhagem, no que concerne ao número inferior de células e baixa atividade de MPO.

O uso das quatro linhagens AIRmax e AIRmin $R R$ ou $S S$ como modelo experimental possibilitou sugerir que a resistência à UC pode ocorrer em indivíduos que possuam o alelo $R$ do gene Slc1lal, contrariamente ao preconizado na literatura que destaca este alelo como permissivo. 
REFERÊNCIAS BIBLIOGRÁFICAS 
Alex P, et al. "Distinct cytokine patterns identified from multiplex profiles of murine DSS and TNBS-induced colitis." Inflammatory bowel diseases 2008 Oct;15(3); 341-352.

Amano, M. T., et al. "A new model of outbred genetically selected mice which present a strong acute inflammatory response in the absence of complement component C5." Inflammation Research 2009 Jan; 58(4): 204-209.

Araki Y, et al. "Dextran sulfate sodium administered orally is depolymerized in the stomach and induces cell cycle arrest plus apoptosis in the colon in early mouse colitis." Oncology reports 2012 Ago; 28(5): 1597-1605.

Araujo, Luiza MM, et al. "Innate resistance to infection by intracellular bacterial pathogens differs in mice selected for maximal or minimal acute inflammatory response." European journal of immunology 1998 Mar 28(9): 2913-2920.

Archer, Nicholas S., Najah T. Nassif, Bronwyn A. O'Brien. "Genetic variants of SLC11A1 are associated with both autoimmune and infectious diseases: systematic review and metaanalysis." Genes and immunity Apr; 2015 16(4): 275

Bain, Calum C., and Allan McI Mowat. "Macrophages in intestinal homeostasis and inflammation." Immunological reviews 2014 260(1): 102-117.

Barton, C. Howard, Simon H. Whitehead, and Jenefer M. Blackwell. "Nramp transfection transfers Ity/Lsh/Bcg-related pleiotropic effects on macrophage activation: influence on oxidative burst and nitric oxide pathways." Molecular medicine 1995 Mar; 1(3): 267-279.

Bento, Allisson Freire, et al. "Evaluation of chemical mediators and cellular response during acute and chronic gut inflammatory response induced by dextran sodium sulfate in mice." Biochemical pharmacology 2012 Dez; 84(11): 1459-1469.

Biozzi, G., et al. "Effect of genetic modification of acute inflammatory responsiveness on tumorigenesis in the mouse." Carcinogenesis 1998 Feb; 19(2): 337-346.

Bischoff, Stephan C., et al. "Intestinal permeability-a new target for disease prevention and therapy." BMC gastroenterology $2014 ; 14(1): 189$.

Blackwell, Jenefer M., and Susan Searle. "Genetic regulation of macrophage activation: understanding the function of Nramp1 (= Ity/Lsh/Bcg)." Immunology letters 1999 Jan; 65(1-2): 73-80.

Bollrath, Julia, et al. "gp130-mediated Stat3 activation in enterocytes regulates cell survival and cell-cycle progression during colitis-associated tumorigenesis." Cancer cell 2009 Feb;15(2): 91-102.

Borrego, Andrea, et al. "Genetic determinants of acute inflammation regulate Salmonella infection and modulate Slc11a1 gene (formerly Nramp1) effects in selected mouse lines." Microbes and infection 2006 Out; 8(12-13): 2766-2771.

Canonne-Hergaux, François, et al. "The Nramp1 protein and its role in resistance to infection and macrophage function." Proceedings of the Association of American Physicians 1999 Jul/Ago;111(4): 283-289.

Chassaing, Benoit, et al. "AIEC pathobiont instigates chronic colitis in susceptible hosts by altering microbiota composition." Gut 2014 Jun; 63(7): 1069-1080. 
Coombes, Janine L., and Kevin J. Maloy. "Control of intestinal homeostasis by regulatory T cells and dendritic cells." Seminars in immunology.. Academic Press, 2007 Abr; 19 (2):116-126

De Franco, Marcelo, et al. "Slc11a1 (Nramp1) alleles interact with acute inflammation loci to modulate wound-healing traits in mice." Mammalian Genome 2007 Mai; 18(4): 263-269.

De Souza, Vinicius RC, et al. "Aryl hydrocarbon receptor polymorphism modulates DMBAinduced inflammation and carcinogenesis in phenotypically selected mice." International journal of cancer 2009 Out; 124(6): 1478-1482.

Di Pace, Roberto Francisco, et al. "Inverse genetic predisposition to colon versus lung carcinogenesis in mouse lines selected based on acute inflammatory responsiveness." Carcinogenesis 2006 Ago; 27(8): 1517-1525.

Egger, Bernhard, et al. "Characterisation of acute murine dextran sodium sulphate colitis: cytokine profile and dose dependency." Digestion 2000 Mar; 62(4): 240-248.

Eichele, Derrick D., and Kusum K. Kharbanda. "Dextran sodium sulfate colitis murine model: An indispensable tool for advancing our understanding of inflammatory bowel diseases pathogenesis." World journal of gastroenterology 2017 Set; 23(33): 6016.

Erben, Ulrike, et al. "A guide to histomorphological evaluation of intestinal inflammation in mouse models." International journal of clinical and experimental pathology 2014 Jul; 7(8): 4557

Erben, Ulrike, et al. "Histomorphology of intestinal inflammation in inflammatory bowel diseases (IBD) mouse models and its relevance for IBD in men." 2016 Fev; Int J Clin Exp Med 9: 408-442.

Frehel, Claude, et al. "Effect of Nramp1 on bacterial replication and on maturation of Mycobacterium avium-containing phagosomes in bone marrow-derived mouse macrophages." Cellular microbiology 2002 Ago; 4(8): 541-556.

Gasteiger, Georg, et al. "Tissue residency of innate lymphoid cells in lymphoid and nonlymphoid organs." Science 2015 Nov; 350(6263): 981-985.

Geremia, Alessandra, et al. "Innate and adaptive immunity in inflammatory bowel disease." Autoimmunity reviews 2014 Jan; 13(1): 3-10.

Grimm, M. C., et al. "Evidence for a CD14+ population of monocytes in inflammatory bowel disease mucosa-implications for pathogenesis." Clinical \& Experimental Immunology 1995 Mai; 100(2): 291-297.

Grivennikov, Sergei, et al. "IL-6 and Stat3 are required for survival of intestinal epithelial cells and development of colitis-associated cancer." Cancer cell 2009 Fev; 15(2): 103-113.

Govoni, Gregory, et al. "Cell-specific and inducible Nramp1 gene expression in mouse macrophages in vitro and in vivo." Journal of Leukocyte Biology 1997 Ago; 62(2): 277-286.

Hisamatsu, Tadakazu, et al. "Immune aspects of the pathogenesis of inflammatory bowel disease." Pharmacology \& therapeutics 2013 Mar; 137(3): 283-297.

Ibanez, Olga M., et al. "Genetics of nonspecific immunity: I. Bidirectional selective breeding of lines of mice endowed with maximal or minimal inflammatory responsiveness." European journal of immunology 1992 Out; 22(10): 2555-2563.

Ito, Reiko, et al. "Involvement of IL-17A in the pathogenesis of DSS-induced colitis in mice." Biochemical and biophysical research communications 2008 Dez; 377(1): 12-16. 
Jabado, Nada, et al. "Natural resistance to intracellular infections: natural resistance-associated macrophage protein 1 (Nramp1) functions as a $\mathrm{pH}$-dependent manganese transporter at the phagosomal membrane." Journal of Experimental Medicine 2000 Out 192(9): 1237-1248.

Jiang, Hui-Rong, et al. "Influence of Slc11a1 (formerly Nramp1) on DSS-induced colitis in mice." Journal of leukocyte biology 2009 Abr; 85(4): 703-710.

Kamezaki, Kenjirou, et al. "Roles of Stat3 and ERK in G-CSF Signaling." Stem cells 2005 Out; 23(2): 252-263.

Katz, Iana Suly Santos, et al. "7, 12-Dimethylbenz (a) anthracene-induced genotoxicity on bone marrow cells from mice phenotypically selected for low acute inflammatory response." DNA repair 2016 Jan; 37: 43-52.

Katz, Iana Suly Santos, et al. "7, 12-dimethylbenz (a) anthracene-induced myelotoxicity differs in mice selected for high or low acute inflammatory response: relationship with aryl hydrocarbon receptor polymorphism." International journal of toxicology $2014 \mathrm{Fev}$; 33(2): 130-142

Khan, Waliul I., et al. "Critical role of MCP-1 in the pathogenesis of experimental colitis in the context of immune and enterochromaffin cells." American Journal of PhysiologyGastrointestinal and Liver Physiology 2006 Mai; 291(5): G803-G811.

Khor, Bernard, Agnes Gardet, and Ramnik J. Xavier. "Genetics and pathogenesis of inflammatory bowel disease." Nature 2011 Jun; 474(7351): 307.

Kitajima, Shuji, Shigenobu Takuma, and Masatoshi Morimoto. "Changes in colonic mucosal permeability in mouse colitis induced with dextran sulfate sodium." Experimental animals 1999 Dez; 48(3): 137-143

Kojima, Y., et al. "Inflammatory bowel disease is associated with a novel promoter polymorphism of natural resistance-associated macrophage protein 1 (NRAMP1) gene." Tissue Antigens 2001 Set; 58(6): 379-384.

Ko, Yanna, et al. "Inflammatory bowel disease environmental risk factors: a population-based case-control study of Middle Eastern migration to Australia." Clinical Gastroenterology and Hepatology 2015 Ago; 13(8): 1453-1463.

Jurjus, Abdo R., Naim N. Khoury, and Jean-Marie Reimund. "Animal models of inflammatory bowel disease." Journal of pharmacological and toxicological methods 2004 Set/Out; 50(2): 8192.

Legaki, Evangelia, and Maria Gazouli. "Influence of environmental factors in the development of inflammatory bowel diseases." World journal of gastrointestinal pharmacology and therapeutics 2016 Fev; 7(1): 112.

Li, Y. I., et al. "Disease-related expression of the IL6/STAT3/SOCS3 signalling pathway in ulcerative colitis and ulcerative colitis-related carcinogenesis." Gut 2010 Fev; 59(2): 227-235.

Lissner, Donata, et al. "Monocyte and M1 macrophage-induced barrier defect contributes to chronic intestinal inflammation in IBD." Inflammatory bowel diseases 2015 Jun; 21(6): 12971305.

Littman, Dan R., and Eric G. Pamer. "Role of the commensal microbiota in normal and pathogenic host immune responses." Cell host \& microbe 2011 Out; 10(4): 311-323.

Mann, Elizabeth R., and Xuhang Li. "Intestinal antigen-presenting cells in mucosal immune homeostasis: crosstalk between dendritic cells, macrophages and B-cells." World journal of gastroenterology: WJG 2014 Ago; 20(29): 9653. 
Maria, Durvanei Augusto, et al. "Pulmonary adenoma susceptibility 1 (Pas1) locus affects inflammatory response." Oncogene 2003 Jan; 22(3): 426.

Melgar, Silvia, Agneta Karlsson, and Erik Michaëlsson. "Acute colitis induced by dextran sulfate sodium progresses to chronicity in C57BL/6 but not in BALB/c mice: correlation between symptoms and inflammation." American Journal of Physiology-Gastrointestinal and Liver Physiology 2005 Jun; 288(6): G1328-G1338.

Molodecky, Natalie A., et al. "Increasing incidence and prevalence of the inflammatory bowel diseases with time, based on systematic review." Gastroenterology 2012 Jan; 142(1): 46-54.

Mowat, Allan McI, and Calum C. Bain. "Mucosal macrophages in intestinal homeostasis and inflammation." Journal of innate immunity 2011 Out; 3(6): 550-564.

Mudter, Jonas, and Markus F. Neurath. "Il-6 signaling in inflammatory bowel disease: pathophysiological role and clinical relevance." Inflammatory bowel diseases 2007 Ago; 13(8): 1016-1023.

Mulero, Victoriano, et al. "Solute carrier 11a1 (Slc11a1; formerly Nramp1) regulates metabolism and release of iron acquired by phagocytic, but not transferrin-receptor-mediated, iron uptake." Biochemical Journal 2002 Abr; 363(1): 89-94.

Munyaka, Peris Mumbi, et al. "Acute dextran sulfate sodium (DSS)-induced colitis promotes gut microbial dysbiosis in mice." Journal of basic microbiology 2016 Abr; 56(9): 986-998.

Muraguchi, A. T. S. U. S. H. I., et al. "The essential role of B cell stimulatory factor 2 (BSF-2/IL-6) for the terminal differentiation of B cells." Journal of Experimental Medicine 1988 Fev;167(2): 332-34

Műzes, Györgyi, et al. "Changes of the cytokine profile in inflammatory bowel diseases." World journal of gastroenterology: WJG 2012 Nov;18(41): 5848.

Nell, Sandra, Sebastian Suerbaum, and Christine Josenhans. "The impact of the microbiota on the pathogenesis of IBD: lessons from mouse infection models." Nature Reviews Microbiology 2010 Jul; 8(8): 564.

Neurath, Markus F., Susetta Finotto, and Laurie H. Glimcher. "The role of Th1/Th2 polarization in mucosal immunity." Nature medicine 2002 Jun; 8(6): 567.

Ni, J., S. F. Chen, and D. Hollander. "Effects of dextran sulphate sodium on intestinal epithelial cells and intestinal lymphocytes." Gut 1996 Ago; 39(2): 234-241.

Odenwald, Matthew A., and Jerrold R. Turner. "The intestinal epithelial barrier: a therapeutic target?." Nature reviews Gastroenterology \& hepatology 2017 Nov; 14(1): 9.

Okayasu, Isao, et al. "A novel method in the induction of reliable experimental acute and chronic ulcerative colitis in mice." Gastroenterology 1990 Mar; 98(3): 694-702.

Okumura, Ryu, and Kiyoshi Takeda. "Maintenance of intestinal homeostasis by mucosal barriers." Inflammation and regeneration 2018 Abr; 38(1): 5.

Palm, Noah W., Marcel R. de Zoete, and Richard A. Flavell. "Immune-microbiota interactions in health and disease." Clinical immunology 2015 Ago; 159(2): 122-127.

Perše, Martina, and Anton Cerar. "Dextran sodium sulphate colitis mouse model: traps and tricks." BioMed Research International 2012 Mar; 2012:718617 
Peters, L. C., et al. "Slc11a1 (formerly NRAMP1) gene modulates both acute inflammatory reactions and pristane-induced arthritis in mice." Genes and Immunity 2007 Nov; 8(1): 51.

Qualls, Joseph E., et al. "Suppression of experimental colitis by intestinal mononuclear phagocytes." Journal of leukocyte biology 2006 Ago; 80(4): 802-815.

Randhawa, Puneet Kaur, et al. "A review on chemical-induced inflammatory bowel disease models in rodents." The Korean journal of physiology \& pharmacology 2014 Ago;18(4): 279288.

Ribeiro, Orlando G., et al. "Convergent alteration of granulopoiesis, chemotactic activity, and neutrophil apoptosis during mouse selection for high acute inflammatory response." Journal of leukocyte biology 2003 Out; 74(4): 497-506.

Shouval, Dror S., and Paul A. Rufo. "The role of environmental factors in the pathogenesis of inflammatory bowel diseases: a review." JAMA pediatrics 2017 Out; 171(10): 999-1005.

Solomon, Livingstone, et al. "The dextran sulphate sodium (DSS) model of colitis: an overview." Comparative clinical pathology 2010 Jun; 19(3): 235-239.

Stevceva, Liljana, et al. "Dextran sodium sulphate-induced colitis activity varies with mouse strain but develops in lipopolysaccharide-unresponsive mice." Journal of gastroenterology and hepatology 1999 Jan; 14(1): 54-60.

Strober, Warren, Ivan J. Fuss, and Richard S. Blumberg. "The immunology of mucosal models of inflammation." Annual review of immunology 2002 Abr; 20(1): 495-549.

Sun, Manyi, Li Zhang, and Songli Shi. "Associations between NRAMP1 polymorphisms and susceptibility to ulcerative colitis/Crohn's disease: A Meta-analysis." Immunological investigations 2016 Mar; 45(3): 255-270.

Takeda, Kiyoshi, et al. "Enhanced Th1 activity and development of chronic enterocolitis in mice devoid of Stat3 in macrophages and neutrophils." Immunity 1999 Jan; 10(1): 39-49.

Tatiya-aphiradee, Nitima, Waranya Chatuphonprasert, and Kanokwan Jarukamjorn. "Immune response and inflammatory pathway of ulcerative colitis." Journal of basic and clinical physiology and pharmacology 2018 Mai 30(1): 1-10.

Tsang, K. Y., et al. "Human recombinant interleukin-6 enhances antibody-dependent cellular cytotoxicity of human tumor cells mediated by human peripheral blood mononuclear cells." Cancer Immunology, Immunotherapy 1991 Jan; 34(1): 9-16.

Ungaro, R., Mehandru, S., Allen, P. B. et al. "Ulcerative colitis" ,The Lancet, 2017 Mai; 389(10080): 1756-1770.

Valdez, Yanet, et al. "Nramp1 expression by dendritic cells modulates inflammatory responses during Salmonella Typhimurium infection." Cellular microbiology 2008 Jul; 10.8: 1646-1661.

Vancamelbeke, Maaike, and Séverine Vermeire. "The intestinal barrier: a fundamental role in health and disease." Expert review of gastroenterology \& hepatology 2017 Jun; 11(9): 821-834.

Vidal, Silvia M., et al. "Natural resistance to infection with intracellular parasites: isolation of a candidate for Bcg." Cell 1993 Mai;73.3 : 469-485.

Vidal, Silvia M., et al. "Natural resistance to intracellular infections: Nramp1 encodes a membrane phosphoglycoprotein absent in macrophages from susceptible (Nramp1 D169) mouse strains." The Journal of Immunology 1996 Out; 157(8): 3559-3568. 
Vigar, Nicole D., et al. "Pristane-induced arthritis in mice selected for maximal or minimal acute inflammatory reaction." European journal of immunology 2000 Aug; 30(2): 431-437.

Waldner, Maximilian J., and Markus F. Neurath. "Master regulator of intestinal disease: IL-6 in chronic inflammation and cancer development." Seminars in immunology. Academic Press, 2014 Fev; 26(1): 75-79

Wells, Jerry M., et al. "Homeostasis of the gut barrier and potential biomarkers." American Journal of Physiology-Gastrointestinal and Liver Physiology 2016 Dez; 312(3) : G171-G193.

Wessling-Resnick, Marianne. "Nramp1 and other transporters involved in metal withholding during infection." Journal of Biological Chemistry 2015 Jul; 290(31): 18984-18990.

Wirtz, Stefan, et al. "Chemically induced mouse models of intestinal inflammation." Nature protocols 2007 Mar; 2(3): 541.

Wojciechowski, Wojciech, et al. "Attenuation of MHC class II expression in macrophages infected with Mycobacterium bovis bacillus Calmette-Guerin involves class II transactivator and depends on the Nramp1 gene." The Journal of Immunology 1999 Set; 163(5): 2688-2696.

Zaahl, Monique G., et al. "The- $237 \mathrm{C} \rightarrow \mathrm{T}$ promoter polymorphism of the SLC11A1 gene is associated with a protective effect in relation to inflammatory bowel disease in the South African population." International journal of colorectal disease 2006 Jul; 21(5): 402. 